REVIEW

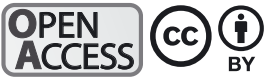

\title{
Climate change and aquaculture: considering biological response and resources
}

\author{
Gregor K. Reid ${ }^{1,2, *}$, Helen J. Gurney-Smith ${ }^{1,3}$, David J. Marcogliese ${ }^{1,4}$, \\ Duncan Knowler ${ }^{5}$, Tillmann Benfey ${ }^{6}$, Amber F. Garber ${ }^{7}$, Ian Forster ${ }^{8}$, \\ Thierry Chopin ${ }^{2,9}$, Kathy Brewer-Dalton ${ }^{10}$, Richard D. Moccia ${ }^{11}$, Mark Flaherty ${ }^{12}$, \\ Caitlin T. Smith ${ }^{13}$, Sena De Silva ${ }^{14}$
}

\author{
${ }^{1}$ St. Andrews Biological Station, Fisheries and Oceans Canada, St. Andrews, NB E5B 0E4, Canada \\ ${ }^{2}$ Canadian Integrated Multi-Trophic Aquaculture Network (CIMTAN), University of New Brunswick, Saint John, NB E2L 4L5, Canada \\ ${ }^{3}$ Department of Biology, University of Victoria, Victoria, BC V8P 5C2, Canada \\ ${ }^{4}$ Science and Technology Branch, Environment and Climate Change Canada, Montreal, QC K1A 0H3, Canada \\ ${ }^{5}$ School of Resource and Environmental Management, Simon Fraser University, Burnaby, BC V5A 1S6, Canada \\ ${ }^{6}$ Department of Biology, University of New Brunswick, Fredericton, NB E3B 5A3, Canada \\ ${ }^{7}$ Huntsman Marine Science Centre, St. Andrews, NB E5B 2L7, Canada \\ ${ }^{8}$ Pacific Science Enterprise Centre, Fisheries and Oceans Canada, West Vancouver, BC V7V1N6, Canada \\ ${ }^{9}$ Department of Biological Sciences, University of New Brunswick, Saint John, NB E2L 4L5, Canada \\ ${ }^{10}$ New Brunswick Department of Agriculture, Aquaculture and Fisheries, Fredericton, NB E3B 5H1, Canada \\ ${ }^{11}$ Department of Animal Biosciences, University of Guelph, Guelph, ON N1G 2W1, Canada \\ ${ }^{12}$ Department of Geography, University of Victoria, Victoria, BC V8P 5C2, Canada \\ ${ }^{13}$ Port of Prince Rupert, BC V8J 1A2, Canada \\ ${ }^{14}$ School of Life and Environmental Sciences, Deakin University, Warrnambool, VIC 3280, Australia
}

\begin{abstract}
The heavy reliance of most global aquaculture on the ambient environment suggests inherent vulnerability to climate change effects. This review explores the potential effects of climate change stressors on aquaculture biology and resources needed to support decision-making for vulnerability assessment, planned adaptation, and strategic research development. Climate change-mediated physiochemical outcomes important to aquaculture include extreme weather, precipitation and surge-based flooding, water stress, ocean acidification, sea-level rise, saltwater intrusion, and changes to temperature, salinity, and dissolved oxygen. Culture practices, environment, and region affect stressor exposure, and biological response between species or populations are not universal. Response to a climate change stressor will be a function of where changes occur relative to optimal ranges and tolerance limits of an organism's life stage and physiological processes; the average magnitude of the stressor over the production cycle; stressor rate of change; variation, frequency, duration, and magnitude of extremes; epigenetic expression, genetic strain, and variation within and between populations; health and nutrition; and simultaneous stressor occurrence. The effects of simultaneous stressors will frequently interact, but may not be fully additive or synergistic. Disease is a major aquaculture limiter, and climate change is expected to further affect plant and animal health through the host and/or infectious agents. Climate change may introduce further complexity to the aquaculture-wild fishery relationship, with over two-thirds of animal aquaculture production dependent on external feed inputs. Higher production costs could be an economic outcome of climate change for many aquaculture sectors. Some aquaculture practices may inadvertently reduce resiliency to climate change, such as a reduction of coastal vegetation, coastal ground-water pumping, and reduction of population variability in pursuit of consistent production traits. Information from the largest aquaculture producers such as China and the top 3 global culture species is still sparse in the literature. This potentially limits thorough understanding of climate change effects on some regional aquaculture sectors.
\end{abstract}

KEY WORDS: Nutrition - Algae - Genetics · Fish health · Acclimation · Economics - Ocean acidification $\cdot$ Extreme weather 


\section{INTRODUCTION}

The FAO reports that climate change threatens our ability to ensure global food security, eradicate poverty, and achieve sustainable development (FAO 2018b). Human-driven global warming is already altering our environment, with far-reaching consequences. Much attention has focussed on its implications for terrestrial systems, but climate change is also altering ocean and aquatic ecosystems in profound ways, with consequent impacts on fisheries and aquaculture, and the livelihoods and communities dependent upon these resources. This review aims to explore potential pathways of climate change effects on aquaculture, from alterations to physical systems and how these could affect changes in biology, economics, and resource usage of cultured species, as a prerequisite to guide adaptation.

Capture fisheries and aquaculture provide 3 billion people with $20 \%$ of their average per capita intake of animal protein and a further 1.5 billion people with about $15 \%$ of their animal protein (HLPE 2014). Seafood is the most highly traded food (Smith et al. 2010), and demand is only expected to increase (World Bank 2013). Aquaculture now provides half of all fish for human consumption (FAO 2016). Capture fisheries landings are reported to have either plateaued around $90 \mathrm{Mt}$ annually (FAO 2018a) or decreased (Pauly \& Zeller 2016) since the mid-1990s. As of $2013,31.4 \%$ of global stocks were overfished, $58.1 \%$ were fully fished, and only $10.5 \%$ were underfished (FAO 2016). While some wild fisheries may experience short-term benefits from climate change, overall global landings are predicted to decrease $10 \%$ by 2050 (Barange et al. 2014).

The intersection of these trends has brought increased attention to the potential of aquaculture to fill the gap. Global aquaculture production has been steadily increasing for decades, reaching $110.2 \mathrm{Mt}$ (including aquatic plants), with the first-sale value estimated at US \$243.5 billion in 2016 (FAO 2018a). Aquatic and marine animal production has reached almost $74 \mathrm{Mt}$, and this is expected to expand to 102 Mt by 2025 (FAO 2016). Almost 600 different aquatic species (FAO 2018a) are cultured in almost 200 countries, nearly a third produced without feed use (e.g. bivalves and filter-feeding carps), and an additional culture of $27.3 \mathrm{Mt} \mathrm{yr}^{-1}$ of seaweeds and other algae (FAO 2016). Global production has largely been driven by China, contributing $60 \%$ to global production, followed by other leading producer nations such as India, Vietnam, Bangladesh, and Egypt. Inland aquaculture systems account for the majority of pro- duction of aquatic animals (47 Mt), with most finfish culture occurring in earthen ponds, although finfish cage culture is expanding where conditions allow (FAO 2016). In developing countries where there is intense competition for space and resources, expansion of culture-based fisheries is expected in coming years, where extensive aquaculture is based on stock and recapture (De Silva 2016). Areas available for the expansion of marine aquaculture are still largely untapped (Gentry et al. 2017). The vast range of species, environments, regions, systems, and practices suggests that many aquaculture sectors and regions will be susceptible to a variety of climate change impacts, and indeed, some of the largest aquaculture producer nations (e.g. China, Vietnam, Bangladesh, Egypt) are predicted to be highly vulnerable to climate change (Handisyde et al. 2017).

Given the potential range of abiotic and biotic climate change stressors, impacts to resources, the diversity of biological response mechanisms, and the potential for stressor interaction, cost-benefit evaluation of aquaculture adaptation efforts is vital. Research and information are needed to support these efforts. At the global level, the volume of aquaculture-relevant climate research becoming available is encouraging, but also daunting. Research into the multiple dimensions of climate change is increasing exponentially (Haunschild et al. 2016, Pedersen et al. 2016, Xu et al. 2016), and literature specific to climate change impacts on aquaculture is still comparatively limited, but is also increasing exponentially (Dabbadie et al. 2018). The rapid publication rate of climate change research makes keeping abreast of aquaculture-relevant literature increasingly difficult, even for experts. This begs the question as to whether there are recurring trends and commonalities that may apply across global aquaculture sectors to help better guide literature searches, decision making, and targeted research to support adaption. At the sector or farm level, focus can be narrowed by following pathways of effects from changes to regional physical systems, the resultant potential for exposure, and range of biological responses. Therefore, rather than structure this review based on culture systems, country, or species, we explore changes to physical systems, possible mechanisms of exposure to these changes, and biological response examples of aquaculture species (if available). Regions and culture groups are emphasized and examples provided where data are available.

Herein we survey a diverse range of literature to explore possible implications of climate change to aquaculture to support pragmatic decision making 
by managers, policy makers, and researchers, needed for vulnerability assessments, planned adaptation, or strategic research development. While there are many potential strategies for adaptation through aquaculture management approaches, this is beyond the scope of this particular review. Studies reviewed herein simulate climate change stressors using projected conditions within, or up to, the end of this century, unless otherwise specified. Where research results are reported, the units of the original study are used. We define a climate change stressor as a physical or biological driver that can be altered by climate change, resulting in the potential for detrimental impacts to an aquaculture species, sector, or resources.

\section{STORMS AND WATER}

\subsection{Sea-level rise}

By the end of the $21^{\text {st }}$ century, it is very likely that sea-level rise will occur in more than $95 \%$ of the ocean area (Stocker et al. 2013). Global mean sea level rose $1.2 \pm 0.2 \mathrm{~mm} \mathrm{yr}^{-1}$ between 1901 and 1990 and accelerated to $3.0 \pm 0.7 \mathrm{~mm} \mathrm{yr}^{-1}$ between 1993 and 2010 (Hay et al. 2015). The rate of sea-level rise over broad regions can be several times larger or smaller than that of global mean sea-level rise for periods of several decades, due to fluctuations in ocean circulation. Oscillations such as the El Niño Southern Oscillations (Cazenave et al. 2014), the Pacific Decadal Oscillation (Mantua et al. 1997), and the Pacific Gyre Oscillation (Di Lorenzo et al. 2008) may cause local convergences of water masses, resulting in higher sea levels (King et al. 2011). Consequently, sea-level rise is not expected to be the same everywhere, and hotspots of accelerated sealevel rise have already been identified, such as the North American Atlantic, where the sea level has risen $~ 3-4$ times higher than the global average (Sallenger et al. 2012).

Sea-level rise has the potential to affect coastal aquaculture operations through loss of culture area (Hargreaves 2014), and greater, more distant salt intrusion into coastal groundwater (Smajgl et al. 2015). Small, gradual increases in sea-level rise are not inconsequential, as the influences to flood inundation are not linear. For example, an increase in sea level by $0.1 \mathrm{~m}$ will increase flood frequency by approximately 3 times (Church et al. 2006, Zhai et al. 2014). In some aquaculture areas such as coastal Vietnam, the tidal amplitude has changed drastically
(Binh et al. 2017), and this can augment seasonal and episodic flooding via storm surges (Wassmann et al. 2004, Rhein et al. 2013).

Ironically, some previous aquaculture practices may actually exacerbate coastal flooding. Mangroves and other coastal vegetation provide natural barriers to coastal flooding, erosion, and storm surges (Arkema et al. 2013). Widespread mangrove clearing in Southeast Asia has occurred primarily from agriculture, but also from aquaculture (Giri et al. 2008). Shrimp farming development, in particular, has resulted in extensive historical mangrove destruction in coastal Sri Lanka (Bournazel et al. 2015), Bangladesh (Didar-Ul Islam \& Bhuiyan 2016), Indonesia (Murdiyarso et al. 2015), Vietnam (Orchard et al. 2015), and many other regions where coastal aquaculture occurs (Hamilton 2013). However, most countries have now banned the clearing of mangrove areas for aquaculture (FAO 2007), and there has been a realization that acid sulphate solids in which mangroves grow do not provide a good environment for shrimp culture (Stevenson et al. 1999), suggesting that mangrove clearing for aquaculture is abating. Some natural mangrove regeneration is now occurring in abandoned shrimp ponds, but growth is expected to be slow (Bournazel et al. 2015). Nevertheless, large areas of coastal mangroves have been removed historically, and remaining mangroves are predicted to be further damaged by climate change (UNEP-WCMC 2006), which may raise additional concerns about their continued effectiveness as coastal defences.

\subsection{Saltwater intrusion}

With sea-level rise, saltwater is shifting landward into regions that previously have not experienced or adapted to salinity (Tully et al. 2019). Surface and near-surface drinking water in low-lying coastal areas, such as the mega-deltas in Vietnam and Bangladesh-India, are most vulnerable to saltwater intrusion, where more than 25 million people are at risk of drinking 'saline' water (Hoque et al. 2016). The rate of intrusion is expected to accelerate, with a $30 \mathrm{~cm}$ sea-level rise in the Mekong Delta predicted by 2050 (Smajgl et al. 2015). Salinity changes may not be a concern for cultured euryhaline species, but saltwater intrusion has already proven problematic for less tolerant species. In some areas of Bangladesh, salinization has impacted crops providing a barrier to freshwater prawn farming in rice paddies, also affecting the drinking water of the prawn farmers 
themselves (Ahmed 2013). Salinity intrusion has already been experienced by some striped catfish Pangasianodon hypophthalmus farmers in Vietnam (Nguyen et al. 2018). In some Vietnamese provinces, sea-level rise from 50 to $75 \mathrm{~cm}$ is expected to increase water levels during the rainy season and salt intrusion during the dry season, thereby threatening production (Nguyen et al. 2014). Sea-level rise in combination with some shrimp farming practices may exacerbate saltwater inundation. Prolonged flow of saline water into coastal shrimp ponds can promote saline percolation into the surrounding soils (DidarUl Islam \& Bhuiyan 2016). Saltwater intrusion may be a possible advantage for some types of aquaculture. Areas rendered unsuitable for agriculture, particularly traditional rice farming, could be repurposed for shrimp farming (De Silva \& Soto 2009).

\subsection{Flooding and extreme weather}

Increases in precipitation-mediated flooding will be problematic for some types of aquaculture, but potentially advantageous for other types. Despite some regional uncertainties, climate models consistently project large rainfall changes occurring for a considerable proportion of the tropics by midcentury (Chadwick et al. 2016). Projections suggest that the largest increase in flood frequency will occur in Southeast Asia, peninsular India, eastern Africa, and the northern half of the Andes (Hirabayashi et al. 2013), although flood frequency is still projected to increase in other regions, such as areas of the USA (Rahmani et al. 2016, Prein et al. 2017) and large portions of Europe (Alfieri et al. 2015). Climate-driven causes of floods may be difficult to tease out, as they will also occur together with other catalysts. Global damage due to flooding is expected to increase 20 times by the end of the 21st century, mainly due to climate forcing in Africa and from the effects of socioeconomic growth in Southeast Asia (Winsemius et al. 2016).

Flooding can cause escapes, introduce predator species into culture ponds, and cause contamination of pond water through debris and waste intrusion (Adhikari et al. 2018, Kais \& Islam 2018). Floodrelated mortalities are not uncommon with pond culture (Bell et al. 2009) and hatcheries. Flood-related fish kills may occur for several reasons, but are predominantly due to low oxygen in flood waters (Idris et al. 2014). While there does not appear to be any documentation on the prevalence of flood damage to aquaculture operations on global or regional scales, an internet search using the terms 'hatchery', 'fish farm', and 'flood' returned numerous media reports of fish mortalities, escapes, or evacuations due to flooding (e.g. Johnson 2011, Brooks 2013, Booth 2014, 69 News 2014, Lawrence 2016). Many of the floods reported by the mainstream English-language media are flash floods related to heavy rainfall in North America and Europe. This is consistent with the increased frequency and intensity of heavy precipitation events in northern Europe and North America, whereas less precipitation is occurring in other regions such as southern Europe and Central America (IPCC 2013). While flooding is largely seen as detrimental to aquaculture in general, there are some aquaculture fisheries that rely on flooding to fill water bodies with wild fish for culture, such as floodplain ponds in Kenya (Kipkemboi et al. 2010), or Whedo aquaculture systems in west Africa (Hauber et al. 2011). Increased flooding could expand culture opportunities in these areas.

Increasing sediment load and potential for contamination have also been highlighted as flood-mediated threats to aquaculture. Floods can promote high inorganic sediment loads in areas of coastal open-water aquaculture and reduce or arrest the filtration rate of shellfish (Rosa et al. 2012). The re-suspension of contaminated sediments could be an additional problem. In laboratory studies under elevated temperature conditions, sediment resuspension is considered a plausible route for rainbow trout Oncorhynchus mykiss contamination (Brinkmann et al. 2013). Increases in rainfall will also increase land run-off, driving nutrients from sewage or agricultural fertilizers into coastal production areas and causing algal blooms, which can reduce dissolved oxygen, again resulting in fish mortalities (Díaz et al. 2009). Shellfish contamination from sewage and agriculture can also be a function of flooding. This is exemplified by a moderate flood event in Tasman Bay, New Zealand, where a lowsalinity plume delivered elevated Escherichia coli and Enterococci concentrations (indicative of raw sewage or manure) to a major shellfish production area, causing terrestrial faecal contamination in shellfish $6 \mathrm{~km}$ offshore (Cornelisen et al. 2011).

Flooding through oceanic storm surges can be devastating for aquaculture. Surge-based flooding will be exacerbated by sea-level rise (see Section 2.1). Increased occurrences of tropical cyclones in the Caribbean and landfall typhoons in East Asia are expected, although changes to hurricanes are less certain (Stocker et al. 2013). There is low confidence in any trend of storm systems formed in middle or higher latitudes, but robust evidence exists for 
increased intensity of tropical cyclones in the North Atlantic basin since the 1970s (Rhein et al. 2013). El Niño events can modulate the development of tropical cyclones (Chand et al. 2017), and a near doubling in the frequency of future extreme El Niño and reciprocal La Niña events is expected within this century (Cai et al. 2014, 2015). Wind stress has increased in some areas, such as the Southern Ocean, and average winter wave heights have increased in the North Atlantic (since the 1950s), with a reported trend of 20 $\mathrm{cm}_{\text {decade }}{ }^{-1}$ (Rhein et al. 2013). Wind intensification is more likely to increase at higher latitudes (Sydeman et al. 2014), which may be linked to stronger warming trends in polar rather than equatorial regions (Baumann \& Doherty 2013).

The increased prevalence of extreme weather events will affect coastal fishers, associated services, and infrastructure (IPCC 2007) and can be destructive to coastal aquaculture operations (Allison et al. 2009, Luening 2013). High winds and waves can destroy structures used for coastal aquaculture such as embankments, pond dikes, sluice gates, hatcheries, electricity poles, and rearing structures (Rahman \& Hossain 2012). These impacts may not only occur at the farm level but can impact entire aquaculture sectors. In 2009, Cyclone Aila destroyed $80 \%$ of shrimp farms in the affected areas of Bangladesh (Kais \& Islam 2018), and 2010 storm events in Mexico devastated 1200 farms, reducing the country's annual tilapia production by $80 \%$ (Reid \& Jackson 2014). Open-water aquaculture is also susceptible to storms, where large-scale escapes from sea cages are correlated with storm events (Jensen et al. 2010). Escapes may promote ecological interactions such as introgression (domesticated ancestry) with wild counterparts (e.g. Bolstad et al. 2017). Counterintuitively, a reduction in wind may also be problematic. McCoy et al. (2017) provided evidence that reduced trade winds during an El Niño in Hawaii decreased surface water mixing, thereby enhancing surface heating and water column stratification in fish ponds, ultimately causing hypoxia and mortalities.

\subsection{Water stress}

It is difficult to partition out climate change-mediated effects from other anthropogenic effects on aquaculture water use. Water stress is linked largely with land usage, and in many regions, there is fierce competition between aquaculture and other priority needs, such as agriculture and urban demand. The rapid expansion of freshwater aquaculture has led to major constraints on land use in key producing countries such as China, Indonesia, Bangladesh, Thailand, and India (Liao \& Chao 2009). It is anticipated that by 2050, numerous culture ponds will be taken over by urbanization, resulting in more widespread use of cages in small water bodies and greater production moving to open-water coastal areas (CostaPierce et al. 2011). At present, however, global inland aquaculture production is greater and still increasing faster than marine aquaculture production, with inland production accounting for $64 \%$ of farmed food fish production (FAO 2018a). As most of this production is concentrated in the tropical and subtropical regions of the globe, climate impacts are likely to produce more significant net effects on the freshwater aquaculture subsector in these regions (De Silva \& Soto 2009).

Over half of the world's inland fish culture occurs in China (FAO 2014), primarily in ponds and river delta areas of southeast China (Wang et al. 2015), which include 1.55 million hectares of fish-rice culture (Shelton, 2014). Information on climate change and Chinese aquaculture is scant in the English language literature. However, regional climate models project the frequency of heatwaves and rainfall extremes to increase over most of the country (Zhang et al. 2006). How this may affect river water resources depends on the region. Since the 1960s, the Yellow River, a large northern catchment sensitive to drying trends, has experienced reduced flow, while the Yangtze River, frequently flooded by monsoon rains in its middle reach, has had a small but significant flow increase (Piao et al. 2010). Nevertheless, compared to 1971-2000, projections for 2071-2100 suggest that mean Yangtze River flow will be similar but variably will increase, while mean Yellow River flow will increase by $22 \%$, with temperatures in both rivers increasing by $1.8^{\circ} \mathrm{C}$ (van Vliet et al. 2013). This uncertainty in reconciling observed changes with future river projections in China is considered a major scientific challenge (Piao et al. 2010). However, precipitation-based increases in major aquacultureproducing regions in China are expected to have a positive effect on profitability, but this must also be contextualized with negative effects such as temperature variability (Li et al. 2016). The limited information on climate change and aquaculture water usage in China may reflect more pressing concerns, such as aquaculture-based eutrophic events (Herbeck et al. 2013) and ground subsidence occurring faster than sea-level rise due to hatchery pumping (Higgins et al. 2013). New measures, such as increased regulation and integrated agriculture-aquaculture systems 
are gradually being implemented to improve environmental conditions and water usage (Lin et al. 2015, Wang et al. 2015).

Freshwater user conflict may also be exacerbated by climate change. While this has not been clearly quantified, climate change-mediated reduction in water supply or quality is apt to compound existing water stress issues. Some water usage conflicts have reached a crisis point in some of the major aquaculture farming regions of the world, such as Bangladesh, a nation of rivers, whose production has been impacted by upstream dams in India (Costa-Pierce et al. 2011). Western countries have not been immune from freshwater aquaculture conflict either, and conflicts with agriculture are detailed by North American aquaculture industry reports (Dodd 2013).

\section{BIOLOGICAL RESPONSE}

\subsection{Water temperature}

Suggestions that aquaculture losses are linked to climate change-driven temperatures are now appearing in the literature, from culture regions such as Vietnam (Binh et al. 2017), Australia (Hobday et al. 2018), and Hawaii (McCoy et al. 2017). The oceans have absorbed over $90 \%$ of the increase in energy in the climate system, causing the upper $75 \mathrm{~m}$ to warm by $0.11^{\circ} \mathrm{C}$ decade $^{-1}$ between 1971 and 2010 (Rhein et al. 2013), and this has probably been underestimated due to data limitations in the Southern hemisphere (Durack et al. 2014). Marine organisms have, on average, expanded the leading edges of their ranges by $72.0 \pm 13.5 \mathrm{~km}$ decade $^{-1}$, generally poleward, while marine phenology in spring has advanced approximately $4.4 \pm 1.1 \mathrm{~d}_{\text {decade }}^{-1}$, but with variability among taxonomic groups (Pinsky et al. 2013, Poloczanska et al. 2013). Depending on the representative concentration pathway (RCP) applied, end-of-century model projections for sea surface temperatures range from $0.71 \pm 0.45^{\circ} \mathrm{C}(\mathrm{RCP}$ $4.5)$ to $2.73 \pm 0.72^{\circ} \mathrm{C}(\mathrm{RCP} 8.5)$ (Howes et al. 2015). Some end-of-century projections (RCP 8.5) suggest large increases for some regional 'hot spots', such as the Arctic, tropics, and North Pacific, in excess of $4^{\circ} \mathrm{C}$ (Bopp et al. 2013, Howes et al. 2015). Marine heat waves will be exacerbated as anthropogenic climate change raises mean temperatures (Schmidt \& Boyd 2016). Rivers are of particular concern, given the large portion of global aquaculture production associated with deltas. Global river water temperatures are projected to increase on average by $0.8-1.6(1.0-2.2)^{\circ} \mathrm{C}$ (under the IPCC Special Report on Emission Scenarios B1-A2 scenario) by the end of the century compared to 1971-2000, with the greatest warming projected for the USA, Europe, eastern China, and parts of southern Africa and Australia (van Vliet et al. 2013).

Anticipating biological outcomes for culture scenarios under climate driven temperature change is not trivial due to biological response variability and crude predictive temperature resolution. At the organism level, temperature can affect aerobic capacity, reproduction, maturation and development, growth rate, nutrition, immune function, and timing of seasonal activities, as detailed below. Further complexity is introduced when temperature effects may differ for different biological processes and life stages within the same organism. For temperature projections, coarse ocean or river delta scales mean that temperature projections are only partially informative. There are prediction uncertainties for temperature at the smaller biologically relevant temporal and spatial scales (Stock et al. 2011, Brander 2013) at which aquaculture species are grown, although predictive resolution is increasing (Khan et al. 2013).

Increased variability and temporal extremes can act as direct or indirect stressors, increasing production risk and superimposing over potential growth rate benefits (Holst \& Yu 2010). Elevated seasonal or annual average temperatures may result in positive effects during some seasons (Morgan et al. 2001) or years, but not in others. In Lake Saroma, Japan, decreasing ice cover and advancing spring phytoplankton blooms in the past decade have promoted good scallop culture production, except during years with East Asian Monsoon and El Niño/La Niña Southern Oscillation events, which promote higher temperatures and decreased production (Liu et al. 2018). Increased winter water temperatures are projected to accelerate the growth rate of 4 abalone species in southern Australia, while the projected summer temperatures are expected to cause a 10-fold increase in juvenile mortality (Russell et al. 2012).

In some instances, increased growth rates due to warmer temperatures have still occurred despite other negative side effects. The annual mean temperature of Lake Huron in Canada has increased, increasing the overall harvest weight of net-pen rainbow trout, irrespective of sub-optimal maximal summer water temperatures (Anon. 2013). Warmer temperatures in Patagonian reservoirs have led to a lack of ovulation and reduced spawning and larval survival of cultured rainbow trout, but ultimately increased overall growth (Báez et al. 2011). 


\subsubsection{Aerobic capacity}

The upper reaches of most ocean regions are experiencing continuous decrease in dissolved oxygen concentration, partially due to increased climate warming (Schmidtko et al. 2017). Oxygen demand to support aerobic processes in ectotherms also increases with temperature, due to its direct effect on metabolic rate. This was clearly demonstrated in a classic study by Fry \& Hart (1948), who showed that the oxygen demand of goldfish Carassius auratus more than doubles with acclimation from 10 to $20^{\circ} \mathrm{C}$, concomitant with a $50 \%$ increase in the oxygen tension below which aerobic metabolism is limited by oxygen availability. Similar results have been obtained for aquaculture species, such as post-smolt Atlantic salmon Salmo salar (Remen et al. 2013). This effect of temperature on aerobic capacity can severely constrain aquatic ectotherms that have limited or no ability to use atmospheric oxygen because gas solubility declines as water temperature rises, and as a result, dissolved oxygen levels often become insufficient to support aerobic functioning - and ultimately life - at some high temperature. This can have far-ranging impacts in aquaculture that affect stocking densities, feed intake and utilization (e.g. Remen et al. 2016), growth rates, water usage, and other basic husbandry and health management practices. Exploring how temperature affects aerobic capacity will provide a better understanding of how climate change could impact species selection, management, and farm productivity.

Within aquaculture, positive or negative responses to temperature will depend on where the change occurs on the aerobic performance curve for a particular life stage or physiological process (Pörtner \& Farrell 2008, Clark et al. 2013). A temperature increase near the lower limit could be beneficial, while an increase near the upper limit will likely be detrimental. The size of the optimal temperature range is also species-specific, with eurythermal species able to operate within a wide range of temperatures, while stenothermal species can only function within a narrow range. Environmental and biotic stressors, such as those expected to accompany climate change (e.g. increased frequency and severity of hypoxic events, changes to salinity, ocean acidification, eutrophication, and changes to pathogen and parasite distributions and abundances), may further reduce the temperature range of aerobic performance, although supporting data are mixed (Lefevre 2016).

Increased oxygen demand may not be problematic in well-oxygenated rearing systems, but could be where oxygen concentration approaches lower-limit thresholds, potentially during 'slack tides' (low current flow and therefore low oxygen supply) during maximal production periods of marine caged fish (Page et al. 2005) or stratification of aquaculture ponds (Pickering et al. 2011). Froehlich et al. (2016) recently explored thermal and minimum dissolved oxygen tolerance across a range of marine species, reporting that larger, slow-growing species tended to be overall more tolerant, and that tropical species showed reduced capacity to withstand a larger range of temperatures and lower oxygen levels simultaneously. Unfortunately, slow-growing species are not preferred for aquaculture for economic reasons.

Some cultured fish, such as Pangasius catfish species (FAO 2018a), are capable of air breathing and are therefore more tolerant of hypoxia. However, there may be other costs of hypoxia, depending on the species of air-breathing fish. These are described in detail by Lefevre et al. (2014) and may include such effects as brachial oxygen loss from the blood to water, increased energy demand, and more surfacing, increasing predator exposure.

\subsubsection{Reproduction, growth, and development}

Temperature influences reproductive performance in poikilotherms (Pankhurst \& Munday 2011). Temperature-mediated changes in embryo survival, fecundity, spawning time, maturation rate, and sex ratio can have major implications for reproductive success and breeding practices. As with other physiological processes, species will have an optional reproductive range (e.g. Fearman \& Moltschaniwskyj 2010). Outside these optimal ranges, reproductive performance may suffer. For example, elevated temperatures impair gonad steroid synthesis and hepatic vitellogenin production, and can dramatically reduce egg fertility and embryo survival in Atlantic salmon (Pankhurst et al. 2011, Anderson et al. 2012). Fewer eggs are produced by African catfish Heterobranchus longifilis under elevated dry season temperatures (Legendre 1986). Egg development time can also be a function of temperature, such as with eggs of the European hake Merluccius merluccius, which demonstrate a development power relationship up to a critical temperature threshold (Guevara-Fletcher et al. 2016).

Small increases in average temperatures across a production cycle may have the potential for increases in growth rate for some aquaculture species, such as mussels and salmon (Reid et al. 2015), within optimal 
temperature thresholds. However, this cannot be assured for all culture species scenarios. Some species may have the potential for compensatory growth (e.g. sea bass Dicentrarchus labrax) where animals cultured at lower temperature will eventually 'catch up' to animals grown at warmer temperatures (Sfakianakis et al. 2013).

Maturation rates can also be influenced by temperature (Wilkinson et al. 2010), which may have positive or negative outcomes for aquaculture, depending on context. Increased maturation can be disadvantageous for some types of production such as salmonid aquaculture, where early maturation redirects energy into gamete production instead of growth, thereby slowing growth and time to reach market weight (McClure et al. 2007). Increases in temperatures for other production systems may be advantageous, such as with the common Japanese conger Conger myriaster, where elevated temperatures can induce oocyte maturation without the need for exogenous hormone treatment (Utoh et al. 2013). Sex ratios and early development may also be influenced by temperature, such as in European seabass D. labrax, where higher temperatures in early life stages reduced the number of faster-growing females compared to males (Sfakianakis et al. 2013).

\subsubsection{Nutritional and digestive metabolism}

Temperature has both direct and indirect effects on nutrition, feeding practices, and behaviours. Basal metabolism is the energy used by animals to maintain normal body functions, excluding growth and voluntary activity. As fish are poikilothermic animals, their basal energy needs are directly impacted by the temperature of the water. As temperature rises, so does the standard metabolic rate (e.g. Glencross \& Bermudes 2010) and consequently, the maintenance requirement for energy and protein (e.g. Lupatsch \& Kissil 2005). However, the degree to which temperatures within an optimum range affect basal metabolism will vary among species (Cho \& Kaushik 1990, Glencross 2007, NRC 2011).

Not only will changes in metabolic rate translate into changes for dietary fuel demand, but temperature may also influence the efficiency by which feed is converted into flesh. This is measured by the feed efficiency ratio (FER, gain/feed) or the reciprocal measure, the feed conversion ratio (FCR, feed/gain). For example, FCR increases (less efficient conversion) with temperature in the juvenile hapuku Polyprion oxygeneios (Khan et al. 2014). For some spe- cies, a several-degree temperature difference can translate into large differences in feed conversion. Increased temperature decreased feed conversion efficiency for the cultured juvenile Australasian sea cucumber Australostichopus mollis grown at $21^{\circ} \mathrm{C}$ by 7 times compared to cucumbers grown at $15^{\circ} \mathrm{C}$ (Zamora \& Jeffs 2012). As with other metabolic processes, feed conversion is apt to have optimal temperature ranges, with decreased efficiency occurring at either end of the range (Britz et al. 1997, Siikavuopio et al. 2012). An example of this is large-sized barramundi Lates calcarifer, which use about a third of their gross energy intake for basic maintenance at $30^{\circ} \mathrm{C}$, compared to only $10 \%$ at $20^{\circ} \mathrm{C}$ (Glencross \& Bermudes 2012). Temperature-driven changes to FCR may also accompany changes in digestibility of specific nutritional categories, such as with fatty acids in salmonids (Hua \& Bureau 2009, Huguet et al. 2015).

The influence of water temperature on nutrient digestibility in aquatic animals is typically minimal. Research on salmonids indicates that changes to protein and lipid digestibly may show minor variations with temperature (Windell et al. 1978, Ng et al. 2004, Amin et al. 2014, Huguet et al. 2015). Some research suggests that gut transit time could be affected by warmer water, as either an increase in the case of yellowtail kingfish Seriola lalandi (Miegel et al. 2010) or a decrease, as with greenlip abalone Haliotis laevigata (Currie et al. 2015). Generally, these studies suggest that elevated water temperatures associated with climate change will have minimal impact on nutrient or energy digestibility by aquatic animals, at least until the optimum range has been exceeded.

\subsubsection{Summary - water temperature}

There is an overall warming trend in the world's oceans and freshwaters, with increases in extreme temperature events and variation at multiple scales, but with the greater uncertainty at the farm scale. Global warming is causing species' range shifts, which suggests the potential for introduction of novel predators, invasive species, and pathogens to some aquaculture areas. Climate-driven temperature changes may increase variation in production success, where positive effects may occur in some seasons or years but not in others. While there is the potential for improved growth with increased temperature, there may be other physiological costs such as poorer feed conversion and effects to maturation and reproduction. Some species with the ability for compensatory 
growth at lower temperatures may not show prolonged increased growth rates at higher temperatures. There is increased potential for hypoxia with warming waters, and in some regions this may favour more tolerant species, such as air-breathing fishes. Anticipating temperature outcomes will benefit from knowledge of optimal and critical temperature thresholds for both physiological processes and different life stages of the species cultured.

\subsection{Ocean acidification}

Oceans absorb $\mathrm{CO}_{2}$ from the atmosphere, providing a buffer to atmospheric levels, but the increased levels of atmospheric $\mathrm{CO}_{2}$ being produced since the Industrial Revolution mean that the oceans are absorbing more $\mathrm{CO}_{2}$. This leads to reductions in seawater $\mathrm{pH}$, carbonate ion concentrations, and calcium carbonate $\left(\mathrm{CaCO}_{3}\right)$ minerals and is a process called ocean acidification. Ocean acidification is already a major issue in some regions for both wild and cultured populations, particularly when superimposed over already acid-promoting conditions, such as coastal upwelling (Adelsman et al. 2012). Most of the aquaculture focus has been on shellfish, and Ekstrom et al. (2015) showed that 16 out of 23 regions in the USA have been exposed to rapid ocean acidification, with communities highly reliant on shelled molluscs to be currently or in the near future at risk from ocean acidification. In the USA, ocean acidification has already impacted shellfish aquaculture in Washington State (WSBR Panel 2012), an industry which directly or indirectly employs over 3200 people and provides an estimated total economic contribution of US $\$ 270$ million (NOAA 2011). The elevated levels of internal $\mathrm{CO}_{2}$ (hypercapnia; Widdicombe \& Spicer 2008) and the reduction in carbonate ions caused by ocean acidification affect the ability of organisms with $\mathrm{CaCO}_{3}$ shells to build their shells (Gazeau et al. 2007), affecting calcification (Wood et al. 2008, Hofmann et al. 2010), internal acid-base regulation (Miles et al. 2007), shell biomineralization and energy metabolism (Beniash et al. 2010, Ivanina et al. 2013), and the proteome (Dineshram et al. 2012).

\subsubsection{Larval shellfish}

As many larval shellfish (defined here as seafood with exoskeletons, including molluscs, crustaceans, and echinoderms) stages contain aragonite, it is expected that this stage would be the most sensitive to dissolution from ocean acidification (Waldbusser et al. 2010). Negative responses have been reported in numerous commercial aquaculture and fisheries species (Gazeau et al. 2013). These include Pacific oysters Crassostrea gigas (Kurihara et al. 2007, Parker et al. 2010, Barton et al. 2012, Timmins-Schiffman et al. 2013), eastern oysters C. virginica (Miller et al. 2009, Talmage \& Gobler 2009), Sydney rock oysters Saccostrea glomerata (Parker et al. 2009, 2010, 2012, Watson et al. 2009), blue mussels Mytilus edulis (Gazeau et al. 2010), Mediterranean mussels M. galloprovincialis (Kurihara et al. 2008), bay scallops Argopecten irradians (Talmage \& Gobler 2009, 2011, Gobler \& Talmage 2013), gastropods (Tahil \& Dy 2016), some crustaceans (Padilla-Gamiño et al. 2013, Small et al. 2016, Emerson et al. 2017), echinoderms (Stumpp et al. 2011, 2013), and hard clams Mercenaria mercenaria (Talmage \& Gobler 2009, 2011, Gobler \& Talmage 2013). Comprehensive summaries including commercial species were presented by Gazeau et al. (2013) and Parker et al. (2013), who reviewed research on the effects of ocean acidification on the fertilization, embryonic, and larval development of commercial gastropod and bivalve species and non-commercial molluscs. Reported responses of bivalve larvae are species-specific and can range from negative to non-significant to positive.

The mechanism by which $\mathrm{CO}_{2}$ and carbonate undersaturation imparts negative effects on calcifying organisms (Gobler \& Talmage 2013) and the dynamics of initial shell formation were, until recently, poorly understood (Barton et al. 2012). Levels of aragonite saturations for Pacific oysters were seen to be stressful at aragonite saturations below 1.7 and corrosive at levels below 1 (Barton et al. 2012), and acute and chronic responses have been documented between 1.2 and 2.0 for other bivalve larvae (Talmage \& Gobler 2009, Gaylord et al. 2011, Dineshram et al. 2012, Hettinger et al. 2012). Ekstrom et al. (2015) used a mean aragonite saturation state of 1.5 to represent a conservative threshold and projected when surface seawaters would reach a chronically stressful state for shelled mollusc larvae in Washington State (2016-2021) and Alaska (2006-2015) in the USA, and in British Columbia in Canada (2006-2015).

Ocean acidification can create co-varying inorganic carbon system variables, and seawater manipulations have shown that larval shell development and growth are dependent upon seawater $\mathrm{CaCO}_{3}$ saturation states and not $\mathrm{pCO}_{2}$ or $\mathrm{pH}$ (Waldbusser et al. 2015). Fassbender et al. (2016) reported 
that highly variable coastal carbonate chemistry may affect the ratio of bicarbonate to hydrogen ions in the natural environment and cautioned against the use of aragonite saturation alone for assessing biological ocean acidification exposures and vulnerabilities. Therefore, some conflicting reports on the impacts of ocean acidification on shellfish responses may be related to the decoupling of elements of the carbonate system, highlighting the need to monitor full seawater carbonate chemistry before interpreting results. In addition, an abundance of quality food may assist in buffering the effects of ocean stressors (Thomsen et al. 2010, 2013, Hettinger et al. 2013, Parisi et al. 2017), so care should be taken in assessing organism responses to laboratory acidification experimentation.

Larvae are crucial for sustaining viable populations, and failures will ultimately lead to negative population effects (Jansson et al. 2013). The smaller juvenile larvae with weaker shells may be subject to increased predation risk due to increased time spent in the water column (Waldbusser et al. 2011), and may suffer latent larval effects such as reduced metamorphosis and fitness potential (Miller et al. 2009). This suggests a fundamental ocean acidification bottleneck during early life history for marine keystone species (Waldbusser et al. 2015), and has obvious impacts for aquaculturists reliant on wild seed collection to populate culture farms or the manipulation of hatchery water quality to ensure larval survival. Juveniles that survived under high $\mathrm{pCO}_{2}$ rearing conditions grew faster when exposed to normal $\mathrm{CO}_{2}$ levels compared to those control larvae grown under constant ambient conditions; however, such growth rates could not overcome the early larval size differences even after 10 mo (Gobler \& Talmage 2013). This highlights how early exposure to high $\mathrm{CO}_{2}$ fluxes could significantly affect current and future bivalve populations and commercial production.

\subsubsection{Juvenile and adult shellfish}

Extreme post-settlement loss of juveniles has often been attributed to factors such as predation (Ólafsson et al. 1994), competition (Ahn et al. 1993), and hydrodynamic dispersion (Roegner et al. 1995), but until relatively recently, research had not addressed dissolution mortality (Green et al. 2009). Studies on the impact of lowered $\mathrm{pH}$ on post-larval hard clams $M$. mercenaria found a size-dependent mortality factor, where larger individuals were able to withstand dis- solution through increased rates of calcification (Waldbusser et al. 2010, Talmage \& Gobler 2011) or by reaching a size at which corrosive conditions did not affect survival (Green et al. 2009). Studies on the calcification, growth, and mortality of juvenile Ruditapes decussatus clams found no effect of $\mathrm{pH}$, which was attributed to naturally elevated total alkalinity and variable physical-chemical characteristics of seawater in coastal, estuarine, and transitional waters, and suggested that biological calcification should not be the only metric for impact (Range et al. 2011). Adults and juveniles may experience reduced calcification and shell growth under acidified conditions (Berge et al. 2006, Gazeau et al. 2007, Miller et al. 2009), but this may vary by populations within a species, as local adaptation may occur (Thomsen et al. 2010, Parker et al. 2011). Transgenerational experimentation has examined the impacts of single and multiple ocean stressor conditioning of broodstock on juvenile offspring (see Section 3.3).

Ocean acidification may also create non-calcium associated problems for aquaculture husbandry. For example, byssus attachment of adult Mytilid mussels was weakened under future $\mathrm{pCO}_{2}$ conditions, which has implications for suspension culture and intertidal communities anchored by mussel beds (O'Donnell et al. 2013). There may be the potential for dwarfing in some species, which would affect production. Studies on non-commercial gastropod species (Nassarius Corniculus and Cyclope neritea) in shallow-water $\mathrm{CO}_{2}$ seeps indicate that dwarfing may confer a physiological advantage through a reduced metabolic energy demand, allowing maintenance of calcification and repair of shell dissolution (Garilli et al. 2015). Fundamentally, ocean acidification is likely to impact marine ecosystems over a range of population- and community-level effects, which in turn may affect species' ranges and loss of species diversity (Gaylord et al. 2015) and could result in a change in culture species under aquaculture.

\subsubsection{Finfish}

While there have been many historical $\mathrm{CO}_{2}$ studies on finfish, ocean acidification per se has only recently been considered. Ocean acidification may affect foraging behaviour and swimming performance, and wild fish can exhibit tissue damage and malformations when cultured under acidic conditions (Frommel et al. 2012, 2014, Ahnelt et al. 2016, Pimentel et al. 2016, Shao et al. 2016). Numerous studies have demonstrated olfactory impairment under acidifica- 
tion in wild fish (Nilsson et al. 2012, Chivers et al. 2014, Chung et al. 2014, Hamilton et al. 2014; reviewed in detail by Leduc et al. 2013). It is unclear if olfactory impairment occurs in cultured fish and what implications this might have. Finfish are routinely raised in high- $\mathrm{CO}_{2}$ environments in recirculating aquaculture systems, often in excess of end-ofcentury predictions, with no apparent ill effects (Ellis et al. 2017). This discrepancy with results from studies on wild fish could be for numerous reasons, including improved nutrition and selective breeding for greater tolerance to elevated $\mathrm{CO}_{2}$ (Ellis et al. 2017). There is also extensive variation among species with respect to innate $\mathrm{CO}_{2}$ tolerance (Damsgaard et al. 2015).

\subsubsection{Macroalgae}

Many species of marine macroalgae (seaweeds) have been cultivated for centuries, but intensive algal culture began about 50 yr ago. The FAO reported 37 separate species or species groups cultivated in 50 countries, with a total annual harvest of 30.1 Mt (wet weight) with roughly $9 \mathrm{Mt}$ destined for human consumption (FAO 2016, 2018a). The majority (99.4\%) of seaweed aquaculture occurs in 7 Asian countries, with China as the largest producer of edible seaweeds (Chopin 2018). Cultured seaweeds are used for food, phycocolloids, and other useful chemicals (Chopin \& Sawhney 2009).

Macro-algal species, which are currently $\mathrm{CO}_{2}$ limited (e.g. Swanson \& Fox 2007), are expected to benefit from increases in atmospheric $\mathrm{CO}_{2}$ and dissolved $\mathrm{CO}_{2}$ in water compared to species that are already $\mathrm{CO}_{2}$-saturated (Beardall et al. 1998). Some fleshy macro-algae, red algae (especially those living in low-light environments), and a few green algae may become more competitive in increased $\mathrm{CO}_{2}$ environments (Hepburn et al. 2011). By contrast, calcified seaweeds (like crustose corallines) will likely be less competitive, as the maintenance of supersaturated conditions at the site of precipitation for crystalline forms of $\mathrm{CaCO}_{3}$ will be more difficult in lower- $\mathrm{CO}_{3}{ }^{2-}$ seawater. $\mathrm{CaCO}_{3}$ already precipitated may also be subject to dissolution (i.e. some species may experience decalcification and reduced survival rate). A meta-analysis by Kroeker et al. (2010) indicated that calcifying macro-algae will be more susceptible to ocean acidification than corals, coccolithophorids, molluscs, echinoderms, crustaceans, fish, fleshy macro-algae, and seagrasses.

\subsubsection{Summary - ocean acidification}

Anthropogenic $\mathrm{CO}_{2}$ production has caused reductions in seawater $\mathrm{pH}$, carbonate ion concentrations, and $\mathrm{CaCO}_{3}$ minerals, collectively described as ocean acidification. Response of shellfish species to experimental ocean acidification has been variable but mostly negative. Experiments suggest that larval stages of shellfish appear most sensitive to dissolution from ocean acidification, with growth and development more dependent upon seawater $\mathrm{CaCO}_{3}$ saturation states than $\mathrm{pCO}_{2}$ or $\mathrm{pH}$. Larger juvenile and adult individuals may have greater ability to withstand dissolution through increased rates of calcification or by reaching a size at which corrosive conditions are less impactful. In areas of naturally high $\mathrm{CO}_{2}$ seeps, some species have adapted by dwarfing. This is presumably not a response desirable for aquaculture species. Economic losses in shellfish hatcheries have already occurred where ocean acidification has superimposed over areas of elevated $\mathrm{CO}_{2}$ from upwelling. While experimental evidence suggests that some wild finfish species may be susceptible to high $\mathrm{CO}_{2}$, negative impacts to finfish raised in routine high $\mathrm{CO}_{2}$ conditions are not typically seen in aquaculture. This suggests caution in the extrapolation of wild species laboratory studies to aquaculture production scenarios. Some macro-algal species that are $\mathrm{CO}_{2}$-limited may benefit from ocean acidification, whereas calcifying species may not, potentially influencing future species selection for culture.

As the bulk of global aquaculture occurs in freshwater, ocean acidification may seem less problematic overall compared to other climate change stressors. However, given the potential limiters for freshwater aquaculture expansion described herein, largescale global expansion is apt to occur in the marine environment. While this circumvents some problematic issues of freshwater culture, climate change effects in marine systems will have greater potential influence on global production as marine-based culture expands.

\subsection{Genetics and a changing climate}

\subsubsection{Acclimation}

Within a population, individuals have the capacity to behave, appear, and function (physiologically and phenologically) differently than the average characteristics of an organism within a population, defined as phenotypic plasticity. This suggests that within a 
population, there may be individuals which may respond better to climate stressors than others, and this acclimation, or acclimatization, may allow organisms to function in new environments (Sunday et al. 2014). The capacity of a population to buffer a response may be linked to the strength and the rapidity of the change experienced. For example, there may be metabolic shifts to compensate for increased demands in a stressful environment which assist in maintaining growth, but if the change is sudden and large (e.g. extreme events), a tolerance level may be reached. Warmer larval-rearing temperatures cause an irreversible plastic response during early ontogenesis, resulting in increased body masses and hypoxia tolerance in juvenile common sole Solea solea (Zambonino-Infante et al. 2013). Temperature change can be linked to specific gene expression such as heat tolerance in Arctic charr Salvelinus alpinus (Quinn et al. 2011) and in the spleen transcriptome (Hori et al. 2013) and immune-related genes in blood cells (Pérez-Casanova et al. 2008) of Atlantic cod Gadus morhua. Nevertheless, extensive plasticity in finfish is not universal for all traits, species, stressors, or stressor levels. A lack of plasticity in combination with reduced genetic diversity for arrhythmic heart temperature in Chinook salmon Oncorhynchus tshawytscha has constrained the upper thermal limit, and catastrophic wild population loss is projected under the year 2100 maximum warming scenario (Munoz et al. 2015). Whether plasticity increases the time available for adaptation or slows the pace of adaptation by shifting the mean phenotype in a direction that weakens selective pressure, remains less clear (Gaylord et al. 2015). Ultimately, plasticity has implications for how entire ecosystems may respond to climate change stressors (Hennon et al. 2015).

\subsubsection{Adaptation potential}

Many desirable aquaculture traits (e.g. disease resistance, growth rate) are dependent on the interaction of numerous genes, gene sequences, or loci. A number of studies on commercial species have examined the impacts of parental exposure on offspring adaptation potential. Transgenerational acclimation potential to ocean acidification has been reported for invertebrates, including the green sea urchin Strongylocentrotus droebachiensis (Dupont et al. 2013) and the Sydney rock oyster Saccostrea glomerata (Parker et al. 2012). Studies over 3 generations of mussels (Mytilus edulis) from $\mathrm{CO}_{2}$-enriched and non- enriched habitats have shown short-term selective responses of traits directly affected by ocean acidification and long-term adaptation potential, but it is uncertain if this may actually improve population stability over the longer term (Thomsen et al. 2017). A recent study with the Manila clam Ruditapes philippinarum (Zhao et al. 2018) found that transgenerationally acclimated clams may preferentially extract internal metabolic carbon rather than transport external seawater inorganic carbon to build shells, and suggested that these clams may implement a more efficient energy-utilizing strategy for mitigating ocean acidification which may improve future resiliency. However, transgenerational acclimation is not universally assured and may be a function of trait heritability and selection pressure (Hoffmann \& Sgro 2011). For example, increased tolerance to ocean acidification was not apparent in next-generation spiny damselfish Acanthochromis polyacanthus (Welch et al. 2014), and exposure to multiple climate stressors may actually be maladaptive for the offspring of some species, such as Sydney rock oysters (Parker et al. 2017). Changes in species' range expansions may also lead to hybridization and introgression between closely related species, which may affect the phenotypic variation in the subsequent offspring (Chown et al. 2015), thereby potentially impacting production traits and overall fitness of aquaculture organisms.

\subsubsection{Selection}

Selective breeding is regularly employed in aquaculture operations to increase desirable production traits. There is good evidence suggesting that significant genetic change in many aquatic species (e.g. salmonids and oysters) can occur over relatively few generations (Allendorf \& Phelps 1980, Taris et al. 2006, 2007, Barnes et al. 2011, Crozier \& Hutchings 2014). This artificial selection pressure may reduce genetic diversity, overall population fitness, and resiliency to future environmental change (Evans et al. 2015). In shellfish, where broodstock are often sourced from the wild or maintained in wild conditions, environmental change may drive population genetic variability over generations. For example, an analysis of genetic and phenotypic population clines in areas experiencing ocean acidification via upwelling suggests that shellfish may exhibit local adaptation to ocean acidification, but this adaption may result in reduced genetic variation and therefore capacity for future adaptation to other challenges (Gaitán-Espitia et al. 2017), such as diseases and 
pathogens. Therefore, selection through controlled processes, such as hatcheries and breeding programmes, may not be reflective of production traits which are highly sensitive to changes in the coastal growing environment (Sae-Lim et al. 2017).

Epigenetics examines the interaction of phenotype and environment, where phenotypic changes may be heritable. This does not involve changes to the genetic sequence itself, but may generate changes in gene expression through DNA methylation or histone modification. Epigenetic capacity in response to environmental cues has been studied extensively for some species groups, such as teleosts (Pittman et al. 2013, Gavery et al. 2018), intertidal marine invertebrates (Roberts \& Gavery 2012, Padilla \& Savedo 2013, Olson \& Roberts 2014), and aquatic gastropods (Bourdeau et al. 2015), and to a lesser extent, marine plants (Padilla \& Savedo 2013). In a review of epigenetic considerations for aquaculture, Gavery \& Roberts (2017) discussed areas where epigenetics may be applied, discussing key areas of environmental manipulation and epigenetic selection to produce animals with desired phenotypes, thereby significantly affecting productivity and sustainability. A study of genetics and epigenetics in Oncorhynchus mykiss showed differentially methylated genes between hatchery and wild fish, providing support that epigenetic mechanisms in the selective hatchery environment may be linked to adult phenotypes and may be inherited by future generations (Gavery et al. 2018).

Breeding programmes, whether crude or comprehensive, originate out of the necessity to create a captive stock or the desire to improve production traits. Ironically, breeding regimens often aim to decrease variability in production by increasing consistency of desirable traits such as growth rate, improved survival, and enhanced disease resistance. Consequently, the domestication of animals in some breeding programmes may inadvertently reduce variability and stock adaptive capacity or disregard specific traits important to future climate change scenarios (Gurney-Smith et al. 2017).

\subsubsection{Summary - genetics and a changing climate}

There is a high degree of variation in genetic and epigenetic responses between species and populations, and within populations and life stages. Consequently, some individuals may respond better to climate stressors than others. Environmental exposure can promote plastic responses in early larval stages, and parental exposure may confer some traits to offspring. Selective breeding may provide an avenue to adapt species to climate change stressors. However, genetic correlations between climate-related traits and those traits presently selected (e.g. specific pathogen or disease resistance) are largely unknown. Also, the rate and capacity at which most aquaculture populations can adapt in response to climate change stressors have not been well quantified, particularly over long-term exposures and multiple generations. Expectations for the natural ability of culture organisms and traditional selective breeding to safeguard against climate change stressors should be tempered given the current state of knowledge.

\subsection{Health}

Health management and disease control are among the greatest challenges faced by aquaculture producers globally (Costello 2009, Harkes et al. 2015, Cottier-Cook et al. 2016), and this is considered a constraint to aquaculture expansion in many regions (Rosa et al. 2012, Cottier-Cook et al. 2016). As global aquaculture production expands, the effects of largescale disease outbreaks have become an increasing economic concern (World Bank 2013, Lafferty et al. 2015). In contrast to the terrestrial realm, research on climate change effects on marine and freshwater diseases is still relatively limited (Karvonen et al. 2010, Rowley et al. 2014), and the scarcity of long-term datasets impedes good understanding of climate change influences on disease levels in situ (Karvonen et al. 2010, Callaway et al. 2012).

While specific outcomes are neither clearly understood nor well defined, climate change will have significant effects on parasitism and disease in both freshwater and marine ecosystems (Marcogliese 2001, 2008) in which most aquaculture occurs. Some of the most potentially damaging, but least predictable, effects of climate change in these ecosystems relate to the emergence, translocation, and virulence of diseases, parasites, and pathogens (Callaway et al. 2012). As the environment changes, conditions may become more favourable for nonindigenous hosts, and vectors may be translocated through gradual migration (Cook et al. 1998) or sudden events, such as storms (Scheibling \& Lauzon-Guay 2010, Buchwald et al. 2015) and tsunamis (Floyd 2016), creating the potential for novel disease emergence (Zell et al. 2008, Okamura 2016).

Along with the locality and magnitude of environmental changes, rates must also be considered. 
Changes at the scale of years to decades may provide a good window for biological adaptation or aquaculture management response. However, the seasonality of many aquaculture diseases (Bowden et al. 2007), or their rapid proliferation under extreme environmental conditions, suggest strong potential for climate change to impact aquaculture health through rapid environmental fluctuations (Kautsky et al. 2000, Selvam et al. 2012, Li et al. 2016, Morash \& Alter 2016) or the onset of extremes (Callaway et al. 2012). Increasing frequency of extremes, such as anomalous thermal events, may also reduce the capacity for recovery between events (Baker et al. 2008, Eakin et al. 2010, Burge et al. 2014). The projected near-doubling of El Niño (Cai et al. 2014) and La Niña events (Cai et al. 2015) over this century implies increased potential for extreme seasonal changes across the globe, and these will superimpose over more progressive, gradual changes.

It is anticipated that climate change will affect disease through enhanced parasite/pathogen metabolic rates (e.g. affecting development, transmission, survivability, and virulence), changes to the host (e.g. distribution, behaviour, physiology), or compromised host immune function (Marcogliese 2008, Callaway et al. 2012, Chiaramonte et al. 2016). Potential pathways of effects are detailed in Fig. 1. However, predicting specific outcomes is highly challenging for the following reasons: different pathogen or parasite life history traits will show varying responses to temperature (Marcogliese 2016); climate change effects will occur simultaneously with other anthropogenic stressors and may work cumulatively or synergistically to exacerbate negative effects on host organisms and populations (Marcogliese 2008); multiple climate change stressors will also occur in combination, both acute and long-term; projected magnitudes of environmental changes at smaller scales of relevance to discrete aquaculture operations are much more uncertain compared to regional-scale projections; hosts, pathogens, and parasites have adaptive capacity either through long-term evolution (Okamura \& Feist 2011) or short-term epigenetic response (the extent of which has not been clearly quantified or qualified; see Section 3.3); parental exposure to an environmental stressor may also influence off- spring resistance, depending on the duration of exposure (Suckling et al. 2014, 2015); and exposure to environmental stressors in early life stages may also direct some species along different developmental pathways with differing capacity for tolerance (see Section 3.3).

The various effects of climate change on aquatic systems (e.g. changes to temperature, precipitation, salinity, acidification, oceanic circulation, water levels and flow, eutrophication, stratification, ice cover, ultraviolet radiation) all have the potential to affect host-parasite interactions (Marcogliese 2001, 2008) and aquatic animal health. Here, we explore possible effects of climate change on physio-chemical stressors and resultant disease and immune function as considerations for potential outcomes.

\subsubsection{Water temperature and infection}

There is a contrast between the well-documented and forecasted increase in temperature and the paucity of information regarding potential effects on waterborne microbial pathogens in general (Funari et al. 2012). Nevertheless, there are known relationships between disease and temperature (MarcosLópez et al. 2010). Burge et al. (2014) reviewed over 30 studies within the marine environment where disease outbreaks have been linked to temperature

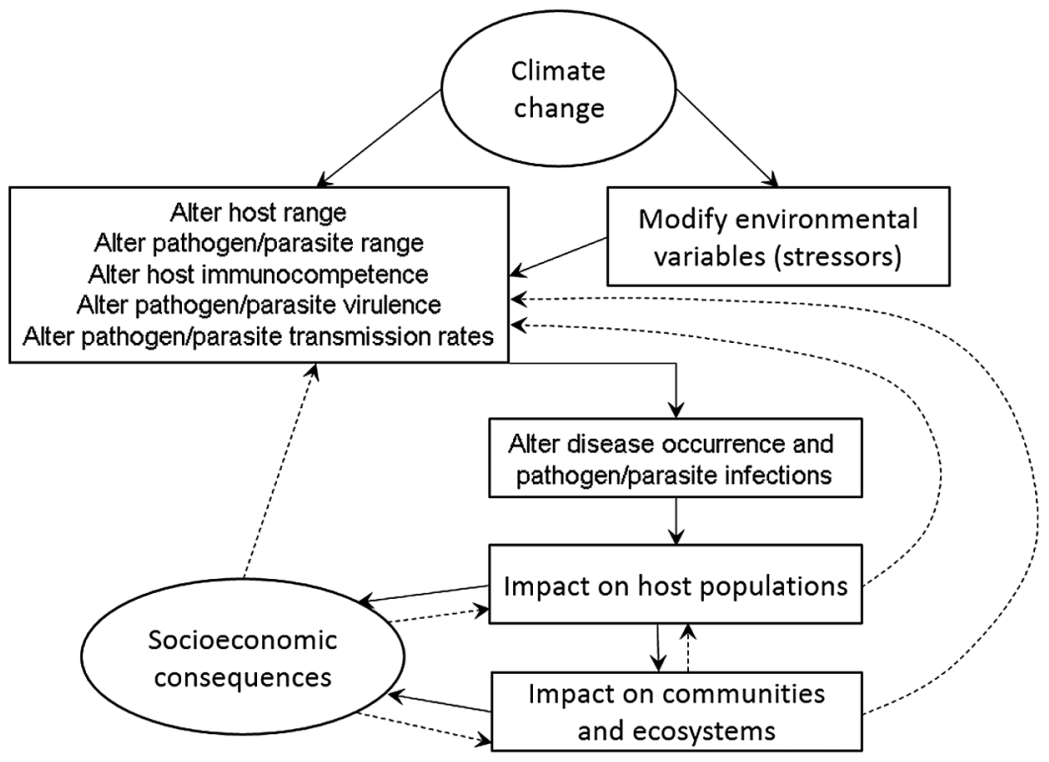

Fig. 1. Schematic representation of climate change effects on pathogens/ parasites and their hosts. Effects will cascade, impacting host populations, communities, and ecosystems (solid lines). Effects will be further modified by interactions with other stressors and environmental variables. Population and community effects will feed back to hosts, their pathogens, and parasites (dashed lines). Modified from Marcogliese (2008) 
across a range of species groups and infectious agents. Exploring the dynamics of tropical aquaculture diseases suggests that warming waters may generally facilitate infection and mortality. Aquaculture diseases at lower latitudes progress more rapidly and have higher cumulative mortality, with tropical countries suffering proportionally greater losses during disease outbreaks, having less time to mitigate losses (Leung \& Bates 2013).

Temperature variability may affect disease dynamics to a greater degree than simple increases in temperature (Rohr et al. 2011, Altizer et al. 2013). Indeed, epizootics of marine trematodes in coastal host populations are predicted to be more common during years when the North Atlantic Oscillation index is high (Mouritsen \& Poulin 2002). However, while modelled increase in seasonal temperature variation has predicted increased growth rate of sea lice populations, the response was of lesser magnitude compared to increases in mean temperature (Groner et al. 2014). Temperature variability, its magnitude and frequency, and acclimation temperatures can differentially affect parasite and host life history traits (Marcogliese 2016).

Not all infectious organisms are expected to thrive under warming waters (Harvell et al. 2002, Karvonen et al. 2010). Using a $21 \mathrm{yr}$ dataset on bacterial and protozoan pathogens in fish farms from northern Finland, the latter authors showed that while the prevalence of 2 agents (the ciliate Ichthyophthirius multifiliis and the bacterium Flavobacterium columnare) increased with mean water temperature over time, others decreased (the flagellate Ichthyobodo necator) or showed no change (the ciliate Chliodonella sp.). Parasites and pathogens are subject to many of the same environmental constraints as other aquatic organisms, and their ranges tend to be much narrower (Callaway et al. 2012). Some marine viruses infect their hosts across a very narrow temperature window of only a few degrees, suggesting that rapid temperature changes through this range would reduce the time available for infection (Gubbins et al. 2013). Pathogens associated with cooler water suggest lesser potential for spread under warming conditions, such as some salmonid cold-water diseases (Harvell et al. 2002, Gubbins et al. 2013).

However, there is no assurance that pathogen temperature ranges or virulence will remain static under environmental change. Bacteria, fungi, and viruses have short generation times (Gubbins et al. 2013), with arguably greater opportunity for evolution compared to their hosts (Martin et al. 2010). Warming temperatures within optional ranges are apt to increase the growth rates of aquaculture species (see Section 3.1). Increasing growth rate compresses the host's rearing cycle, and this could favour evolution of increased pathogen virulence (Kennedy et al. 2016). For parasites with complex life cycles, one must consider the net effects of temperature over the parasite's entire life cycle, as physiological tolerances, optimal thermal conditions, and host pathology vary among stages within species (Marcogliese 2016).

\subsubsection{Water quality}

While temperature is an intuitive environmental focus for aquaculture health, other water quality parameters can become health stressors, including changes in $\mathrm{pCO}_{2}$, salinity, dissolved oxygen, and eutrophication. Changes in $\mathrm{pH}$ along with other parameters such as oxygen and temperature have been linked to infections, such as saprolegniasis in carp (Das et al. 2012) and white spot syndrome virus in shrimp and prawns (Selvam et al. 2012). In the marine environment, research on observed and projected effects of ocean acidification suggests potential for negative effects on structural formation of calcifiers, tissue damage, reproduction, development, and growth in numerous species, as detailed in Section 3.2). Research on ocean acidification and effects to marine aquaculture parasites or pathogens is still in its infancy. While it is expected that ocean acidification will affect marine microbial life, impact specifics are poorly understood (Das \& Mangwani 2015, O'Brien et al. 2016), and most host-parasite studies in ocean acidification research have occurred under the umbrella of ecology, not aquaculture (MacLeod 2017). Nevertheless, some recent laboratory simulations may have some relevance to aquaculture. Under ocean acidification conditions, the abundance of Vibrio spp. (a major group of pathogens for numerous marine organisms) appears to increase (Zha et al. 2017), and immune functions of Pacific oysters C. gigas can become impaired, making them more susceptible to Vibrio (Cao et al. 2018). Simulated ocean acidification conditions also appear to impact haemocyte functionality of the blue mussel $M$. edulis (Bibby et al. 2008). While most ocean acidification research associated with disease potential appears negative, there is evidence that the longevity of different life cycle stages of marine trematodes is reduced by decreasing $\mathrm{pH}$ (Marcogliese 2016).

As with temperature and other abiotic parameters, effects of salinity vary among stages of the same par- 
asite species (Lõhmus \& Björklund 2015). Changing salinity may even control certain disease outbreaks. A relative reduction in salinity may control infections as such as Dermo disease in oysters (Burge et al. 2014) and sea lice on salmon (Groner et al. 2016), whereas a relative increase in salinity has been reported to control certain infections such as $V$. vulnificus in hybrid tilapia (Oreochromis sp.) (Chen et al. 2006) and to decrease infection with the parasitic nematode Anguillicoloides (= Anguillicola) crassus in Atlantic eels (Anguilla spp.) (Lefebvre \& Crivelli 2012). Saltwater intrusion and storm surge-based flooding may also increase disease susceptibility of coastal freshwater species. Saltwater intrusion into freshwater prawn culture areas in Bangladesh has already been linked to several viral and bacterial infections (Ahmed 2013), but may also lead to reductions in parasite abundance and diversity (Overstreet 2007, Marcogliese 2016).

In some instances, competing environmental effects will affect water quality and have implications for health with uncertain outcomes. For example, higher temperatures are likely to increase stratification in shrimp ponds with low water exchange, potentially increasing hypoxia, reducing production, and increasing the risk of disease, but increased pond mixing is expected with projected rainfall increase (Pickering et al. 2011).

\subsubsection{Immune functionality}

Climate change-mediated immuno-suppression is complicated, hard to measure, and difficult to tease out from other anthropogenic or environmental stressors at the wider population or ecosystem level (MacKenzie \& Köster 2004). While temperature may affect pathogen growth rates, it is also a principal environmental cue stimulating changes in the immune response of fish (Chiaramonte et al. 2016), affecting both innate and acquired immune responses (Bowden et al. 2007, Buchtíková et al. 2011). It is suggested that innate parameters are active at the lower temperature range of finfish, while acquired immune parameters (e.g. lymphocyte activity, antibody production) are more effective at higher temperatures (Magnadóttir 2006). Above an optimum, immune function can be impaired by increasing temperature (Lõhmus \& Björklund 2015). Shellfish, however, lack a true adaptive immune system and must depend on their innate immune system to overcome disease (Renault 2009). Given the role of temperature in immune functionality, outcomes from seasonal modi- fication by climate change can be expected. Nevertheless, immune response to temperature may vary widely between related species (Matozzo et al. 2012, Branco et al. 2013). One generality that appears robust, however, is that temperature extremes are detrimental to immune function and contribute to disease outbreaks (Martin et al. 2010). Apart from temperature, concurrent changes in water quality parameters, such as ocean acidification and changes in dissolved oxygen, also have implications for immune functionality in various fish (Choi et al. 2007) and shellfish (Mydlarz et al. 2006, Bibby et al. 2008, Hernroth et al. 2012, 2016, Sui et al. 2016).

The interpretation of apparent competing effects reported in the literature introduces further complexity. Exposure to sub-lethal stress may enhance tolerance to a consequent stressor or incur epigenetic changes that lead to sensitivity to other stressors. Physiological stress decreases disease resistance, but stress-induced heat shock proteins may also enhance the tolerance of aquatic organisms to disease (Sung et al. 2011). While temperature is expected to decrease generation time of many bacterial, viral, and fungal diseases, the acquired immune system of finfish is expected to operate more effectively at warming temperatures (assuming the fish are operating within their thermal limits) and, therefore, with greater potential to overcome infection (Gubbins et al. 2013).

\subsubsection{Summary - health}

Disease is a major aquaculture limiter globally, and climate change is expected to further affect plant and animal health through the host and/or infectious agents with uncertain, but potentially profound, outcomes. Environmental conditions may become more favourable for some nonindigenous hosts, and translocated vectors may create the potential for novel disease emergence. Temperature is the most investigated environmental parameter affecting aquatic disease, and numerous studies have linked water temperature with infection potential. Climate changemediated immuno-suppression of hosts is hard to measure and difficult to tease out from other stressors, but temperature extremes are generally detrimental to immune function of aquatic species. The faster progression of diseases in tropical aquaculture regions suggests that globally warming waters may generally facilitate infection, although many tropical culture areas are in developing regions with limited access to health professionals and treatment, which could also be a contributing factor. Nevertheless, not 
all infectious agents will thrive under changing environmental conditions. Parasites and pathogens are subject to many of the same environmental constraints as other aquatic organisms, and their ranges tend to be much narrower. This aspect may seem like a potential equalizer, but shorter life cycles of infectious agents compared to their hosts may provide greater opportunity for evolutionary adaptation. Research on the effects of ocean acidification on aquatic diseases is still in its infancy. Disease is apt to continue as a major aquaculture limiter under climate change, and additional fish health challenges are expected.

\section{BIOLOGICAL RESPONSE TO MULTIPLE STRESSORS}

Until recently, most research on biological response to climate change stressors has focussed on single stressors. As simultaneous increases in $\mathrm{CO}_{2}$ (reduced $\mathrm{pH}$ and aragonite saturation) and temperature will occur together with changes to salinity and in some instances reduced oxygen (Stramma et al. 2012, Boyd et al. 2015), exploring responses to combined stressors will provide important insights for aquaculture adaptation. Stressor combinations that are negatively synergistic may not always be fully additive (i.e. there is interaction), with the greatest biological response often being attributed to a single dominant driver (Brennan \& Collins 2015). Multistressor studies have been initiated only relatively recently, and thus studies focussing on aquaculture species are still limited. We have therefore also drawn examples from the ecological literature to explore the scope of potential effects.

\subsection{Ocean acidification and temperature}

Increased temperature has been referred to as the 'evil twin' of ocean acidification, given the potential for negative synergy (Miller et al. 2015). In the autotrophic world, increased $\mathrm{CO}_{2}$ is expected to enhance productivity. In the Arctic Ocean, for example, this may have a positive fertilization effect on marine autotrophs, while increased temperature should lead to increased planktonic gross primary production; however, the greatest enhancement of primary production is expected to occur under lower temperatures, constrained by spring nutrient and light availability (Holding et al. 2015). In some instances, ocean acidification effects may be mediated by moderate warming by altering the physiology and seawater geochemistry, such as with growth rates of the Mediterranean mussel Mytilus galloprovincialis (Kroeker et al. 2014). In the case of macro-algae, seasonality may affect how $\mathrm{pH}$ and temperature interact. Elevated $\mathrm{pCO}_{2}$ positively affected growth of the bladderwrack seaweed Fucus vesiculosus, alone and/or interactively with warming, although the response pathway (additive, synergistic, or antagonistic) was a function of season and day length (Graiff et al. 2015).

In Atlantic halibut Hippoglossus hippoglossus, different temperatures can result in differences in down- or up-regulation of immune system-related proteins under elevated $\mathrm{CO}_{2}$ (Bresolin de Souza et al. 2014), whereas increased temperature has been associated with increased aerobic scope and cardiac performance, but more so under elevated $\mathrm{CO}_{2}$ (Gräns et al. 2014). For the anemonefish Amphiprion melanopus, elevated temperature had a much stronger influence on reproductive traits compared to a minimal influence of elevated $\mathrm{CO}_{2}$, but offspring quality declined under both increased temperature and $\mathrm{CO}_{2}$ (Miller et al. 2015). Experimental increases in temperature and $\mathrm{CO}_{2}$ each significantly depressed survival, development, growth, and lipid synthesis in 3 species of calcifying bivalves (Mercenaria mercenaria, Crassostrea virginica, and Argopecten irradians), and in $M$. mercenaria and A. irradians larvae, the effects were additive. While reported outcomes of increasing temperature and decreasing $\mathrm{pH}$ for invertebrates are often negative, they are not always additive. Additive negative effects have been reported for the fluted giant clam Tridacna squamosa (Watson et al. 2012) and larvae of the invasive sea star Patiriella regularis (Byrne et al. 2013). However, increased temperature, but not reduced $\mathrm{pH}$, compromised purple sea urchin Heliocidaris erythrogramma fertilization and early development (Byrne et al. 2009). Interactive effects of temperature and $\mathrm{pH}$ have been reported to immunomodulate the striped venus clam Chamelea gallina and the mussel M. galloprovincialis (Matozzo et al. 2012), with effects that were not always linear. Culture experiments with adult Antarctic sea urchins Sterechinus neumayeri demonstrated that with a sufficient acclimation period, there were minimal effects of combined $\mathrm{pH}$ and increased temperature (Suckling et al. 2015).

\subsection{Ocean acidification and dissolved oxygen}

$\mathrm{CO}_{2}$-induced climate change is increasing the extent and severity of both eutrophication-induced hy- 
poxia in coastal ecosystems and naturally occurring oceanic hypoxic zones (Levin \& Breitburg 2015). Eutrophication is expected to increase in the 21st century due to changes in precipitation (Sinha et al. 2017). Neither the occurrence nor the strength of synergistic impacts of low $\mathrm{pH}$ and low dissolved oxygen on biological response is currently predictable nor fully understood (Gobler \& Baumann 2016), although some generalizations are reported. Hypoxia and acidification typically have synergistic negative effects on the growth, survival, and metamorphosis of early life stage bivalves (Gobler et al. 2014), and reduced respiration in various other marine invertebrates (Steckbauer et al. 2015). A handful of speciesspecific responses have been reported to date.

Both hypoxia and low $\mathrm{pH}$ have negative effects on the Korean mussel $M$. coruscus, but with significant interaction, where the effects of low $\mathrm{pH}$ are not as strong as dissolved oxygen and do not seem to aggravate effects of induced hypoxia (Sui et al. 2016). In 3 species of Northwest Atlantic forage fish, acidification alone significantly depressed the post-hatch survival of Menidia beryllina, but not that of M. menidia nor of Cyprinodon variegatus, while hypoxia alone significantly reduced the length of $M$. menidia and $C$. variegatus (DePasquale et al. 2015). Both acidification and hypoxia together had a negative synergistic effect on length of $M$. beryllina larvae, and hypoxia alone delayed hatching of embryos for all 3 species. This suggests a greater sensitivity of early life-stage estuarine fish to low dissolved oxygen compared to low $\mathrm{pH}$ conditions. However, acidified conditions may increase mortality in $M$. beryllina and $M$. menidia when under hypoxic conditions. (Miller et al. 2016).

\subsection{Salinity change and concurrent effects}

Salinity is expected to decrease in most ocean regions (except the north Southern Ocean, South Atlantic, northern subtropical Atlantic), and inland saltwater intrusion is expected to accompany sealevel rise (Boyd et al. 2015, Hoque et al. 2016). As with other combined stressor studies, salinity also has species-specific optimal ranges in combination with other parameters, such as with the red algae Gracilaria verrucosa and G. chorda (Choi et al. 2006) and the green-lipped mussel Perna viridis (Wang et al. 2011).

Interaction with salinity has also been reported for oxygen, temperature, and $\mathrm{pH}$. Wang et al. (2012) discovered significant interactive effects of oxygen and salinity in the green-lipped mussel $P$. viridis, with haemocyte mortality increasing under low salinity and low dissolved oxygen. Guzmán-Agüero et al. (2013) reported a significant interaction effect of temperature and salinity in the Cortez oyster Crassostrea corteziensis, with scope for growth increasing with temperature but decreasing with increased salinity. Interaction between salinity and temperature has been reported in channel catfish Ictalurus punctatus, hybrid catfish (channel catfish female $\times$ blue catfish $I$. furcatus male) and transgenic catfish (Abass et al. 2016). In a 3-factor experiment, assessing effects of different salinity, $\mathrm{pH}$, and temperature, the shell area of Portuguese oyster C. angulata larvae increased under low salinity and elevated temperature but not in other combinations (Thiyagarajan \& Ko 2012). The oxidative status and metabolic capacity of the mussel M. galloprovincialis were negatively affected by low $\mathrm{pH}$ and salinity change, with the potential for impairment of reproductive output, disease resistance, and growth (Freitas et al. 2017). Some salinity response studies have reported that despite interaction with temperature, one parameter may act as the greatest driver. Salinity is more important than temperature for egg hatching success of the barramundi parasite Lernanthropus latis (Brazenor \& Hutson 2013), but temperature is more important than salinity for yolk utilization of sac fry Nile tilapia Oreochromis niloticus (Hui et al. 2015). However, interaction between salinity and temperature does not occur in all situations. Fertilization and hatching success of the noble scallop Chlamys nobilis had a linear relationship with temperature, but not salinity, and with no interaction between them (Lü et al. 2017).

\section{AQUACULTURE ECONOMICS}

Marine and freshwater aquaculture can anticipate various impacts from climate change, some more severe than others, as detailed elsewhere in this review. A key impact from climate change of pertinence for aquaculture is its potential influence on the severity and frequency of extreme weather events. These events can have extensive effects on aquaculture whether climate change is a factor or not. For example, tropical cyclones Sidri in 2007 and Aila in 2009 devastated shrimp aquaculture in coastal Bangladesh. Kais \& Islam (2018) cited damages from the former at US $\$ 36$ million from the loss of up to 54000 shrimp ghers (integrated fish and farm production system), while the latter resulted in damages to $80-90 \%$ of the ghers in key coastal districts, leading to a reduction in shrimp production of as much as $80 \%$. 
While the influence from climate change on extreme weather events is hotly debated and difficult to isolate, some researchers have suggested that it will have more pronounced effects on the severity of events and less so on their frequency (Allison et al. 2011). However, increasing intensity of hurricanes in the future appears not to have been studied in terms of economic effects. Nonetheless, Hernandez-Llamas \& Zarain-Herzberg (2011) examined the influence of hurricane frequency on the economic returns from shrimp raised in floating cages off the northwest coast of Mexico by simulating economic returns with and without the occurrence of hurricanes. They found that the effect of hurricanes on economic returns is pronounced, but can be ameliorated partly by using partial-and-final harvests and by altering grow-out schedules. While we might expect that more severe hurricanes in the future would have a negative impact on economic returns as well, this was not discussed by the authors.

To date, the more technical investigation of economic impacts of climate change on aquaculture has involved intensive modelling exercises of Norwegian salmon farming or more general investigations of effects for aquaculture in the Tropical Pacific region. Lorentzen (2008) analysed the effect of more volatile sea surface temperature on the economics of salmon farming in Norway, while Hermansen \& Heen (2012) considered the impact of temperature changes on the spatial distribution of production and employment. One result is the shift of production further north in response to increasing temperatures, with potential effects on production and transportation costs. A more indirectly related area of research has examined the impact of climate change on important feed fisheries (i.e. reduction fisheries) for salmon, especially the anchoveta Engraulis ringens fisheries of Peru. Increased climate volatility could raise feed costs (Daw et al. 2009), although any such effects would be moderated by increasing use of alternative feed inputs by the industry.

Climate change could lead to a number of other important impacts on the profitability of aquaculture operations. This observation inevitably arises from a casual review of the many physical and biophysical impacts of climate change outlined in earlier sections. For example, Handisyde et al. (2008) argued that changes in sea surface temperature may accelerate fish growth, thereby improving profitability, but if rising ambient sea temperature also leads to declining dissolved oxygen, stocking densities may have to be reduced, yielding offsetting effects from changing sea temperatures on profitability. Besson et al. (2016) examined these influences on cage farming of sea bass Dicentrarchus labrax in the Mediterranean and found that higher than ambient temperatures (to 19.5 and $21^{\circ} \mathrm{C}$ ) created positive effects on profits, while for smaller increases in temperature (to $18^{\circ} \mathrm{C}$ ) the reverse was true. Meanwhile, the prospect of rising sea temperatures and changing salinity levels for the oyster industry in Rhode Island, USA, was analysed by Sproul et al. (2013), who found that the best response was a mix of slow-growing, disease-resistant varieties and fast-growing, less resistant varieties, akin to diversifying an investment portfolio; the appropriate mix depended on the severity of climate change effects. Finally, Gubbins et al. (2013) suggested that with greater climate volatility and the greater occurrence of extreme events, damages to aquaculture infrastructure would increase, resulting in larger stock losses. They further suggested that other types of disturbances, such as harmful planktonic events or fouling of equipment, may worsen and increase costs for restocking, insurance, and cleaning.

Increasing sea levels under climate change will have additional economic impacts. Pickering et al. (2011) pointed out that coastal pond operations affected by sea-level rise will have greater difficulty with rapid drainage and drying of ponds, requiring heightening of pond walls and floors or costly relocation (if possible at all). Nguyen et al. (2014) argued that sea-level rise will worsen the influence of seasonal increases in water level and salt intrusion for catfish farming in Vietnam; aside from the expense of raising protective dykes, they found that farmers may need to switch to more salt-tolerant and potentially less profitable varieties of catfish. In a separate paper, Nguyen et al. (2016) reported that the associated costs for such a breeding programme for salinetolerant striped catfish Pangasianodon hypophthalmus could require long-term investments of up to $0.40 \%$ of production costs, and for upstream Pangasius farms outside the upgraded dyke-protected areas, additional dyking would cost up to $0.34 \%$ of variable costs per hectare. However, Kam et al. (2012) suggested that catfish farmers may be unable to invest in modifying on-farm infrastructure (e.g. raising dykes) due to the industry's marginal profitability, so that public investment at the regional level may be necessary.

Handisyde et al. (2008) cited rising insurance costs as another potential consequence of rising sea levels and a more volatile climate in general. Opportunities may exist in the future for innovative insurance products such as the 'Extreme El Niño Insurance' being 
promoted in Peru, cited as 'the world's first regulated insurance product that makes payouts before losses are incurred' (GlobalAgRisk 2012). Also, changes in disease prevalence and virility add an increased risk to aquaculture operations that reduces potential profits because losses from disease or costs for preventive and treatment measures may increase (Pickering et al. 2011). For example, Álvarez-Salgado et al. (2008) reported that climate change has reduced the upwelling season in northwest Spain and induced longer water retention times in local bays where $15 \%$ of the world supply of marine mussels are cultivated. Consequences include increased disease prevalence and reduced windows for safe harvesting, both of which can have an impact on the industry's economic returns.

Ocean acidification will have substantive repercussions for various farmed species in the aquaculture sector, as detailed in previous sections. Many impacted species are high-valued, so that the economic losses, at least regionally, could be significant. Reported impacts of ocean acidification in the US Pacific region has already resulted in an estimated US \$110 million of lost revenue, and jeopardized 3200 jobs in the shellfish industry (Ekstrom et al. 2015). The ability of a system to respond to such threats will be a result of the level of ecosystem exposure (how real is the threat), social vulnerability (market value of product and number of related jobs), and adaptive capacity (scientific support, political capacity, and diversification potential) (Ekstrom et al. 2015). Bell et al. (2013) cited the case of the lucrative black pearl Pinctada margaritifera industry in the tropical Pacific Ocean, which may be particularly sensitive to increases in sea surface temperature and ocean acidification, since these affect nacre deposition and pearl quality, and increase the susceptibility of pearl oysters to disease.

Production losses from disease may be accentuated by climate change, resulting in increasing operator losses. Diseases in farmed oysters, shrimp, abalone, and finfish (particularly salmon) already cost the aquaculture industry billions of dollars annually (Lafferty et al. 2015), as detailed below. In economic terms, diseases impact aquaculture through outcomes such as decreased productivity, reduction in product quality, and increased processing and treatment or restocking costs. For example, outbreaks of white spot disease, which are associated with warmer temperatures, resulted in economic losses that were as high as US $\$ 6$ billion in Asia in 19921993 and US \$1 billion in Ecuador in 1999. More generally, mitigation costs for the industry in combatting disease and parasitic outbreaks can be enormous. For example, disinfecting and vaccination to prevent infectious haematopoietic necrosis virus in farmed Atlantic salmon in the Pacific Northwest can cost US $\$ 4$ million per farm, while annual global costs to combat sea lice exceed US $\$ 400$ million (Costello 2009). To the extent that these problems are worsened by climate change, the costs would rise further. In addition, where climate change leads to greater risks of contamination of shellfish cultured in coastal and estuarine areas, there will be a concomitant rise in human health concerns (Gubbins et al. 2013), leading to various measurable health costs and lowered economic productivity.

Many balanced assessments of climate change impacts find some potential positive effects, and this would also apply to aquaculture. For example, increased growth rates for some species could improve profitability for some aquaculturists. Moreover, improved surface conditions for freshwater aquaculture species such as tilapia, carp, and freshwater prawns could support expanded livelihood opportunities for inland populations providing that feed supplies are not an issue (Pickering et al. 2011). In China, Li et al. (2016) modelled provincial-level freshwater aquaculture profits as a function of climate variables and showed that profits predominantly will be positively influenced by climate change at more northerly latitudes, at least in the short run. In the worst case, rapidly advancing impacts of climate change, such as rising sea levels, could produce 'environmental refugees' for whom new opportunities may open up in freshwater aquaculture further inland. This perspective identifies aquaculture as a potential adaptive strategy in the face of advancing climate change, as Dey et al. (2016) argued for Fiji. Similarly, it has been suggested that coastal households possessing aquaculture assets are better poised to rebound after extreme events, leading researchers to propose that aquaculture be promoted for income and food security in coastal areas (Karim et al. 2014).

Overall, there has been relatively little exploration of the potential economic consequences of climate change for aquaculture, and more research is needed. While some modelling of the economics of climate change effects has been carried out for Norwegian salmon farming and for a few other species (e.g. Pangasius sp. and shrimp), most aquaculture sectors remain unstudied. Key policy questions with an economic component need further study as well. Examples include the role of subsidies, both destructive subsidies that increase aquaculture production in vulnerable areas and involve susceptible species, 
and needed subsidies for investments in infrastructure and predictive tools to aid in responding to the climate change threat. Dulvy \& Allison (2009) provided several suggestions for 'mainstreaming' marine fisheries and aquaculture into climate change policy processes and emphasized the need to build resilience in these systems and assess vulnerabilities of not just the production operations, but also of the dependent human populations.

\section{FINFISH AND INVERTEBRATE DIETS}

How climate change will affect ingredient sourcing for aquafeeds (De Silva \& Soto 2009, Brugère 2015) and feed management (Shelton 2014) is a pressing concern. Approximately $70 \%$ of total global aquaculture production by weight is dependent upon the supply of external feed inputs (Tacon \& Metian 2015), and a major challenge for long-term sustainability is to reduce dependence on capture fisheries as a source of raw materials for feed formulations (Tacon et al. 2009). Despite great strides in identification and development of alternative ingredients (e.g. meals derived from soy or corn), small pelagic fish (De Silva \& Soto 2009) are still heavily used for aquafeeds, and the reduction fisheries accounted for about $17 \%$ of the global fisheries landings in 2014 (Tacon \& Metian 2015). Climate change may therefore further complicate the relationship between aquaculture and the capture fisheries.

Population fluctuation of reduction-fisheries species, such as sardine Sardinops sagax and anchovy Engraulis mordax, are explained by interacting density-dependent processes and climate forcing (Lindegren et al. 2013, Buchheister et al. 2016). Merino et al. (2010) modelled the interacting effects of climate-driven fluctuations on reduction-fisheries stocks and expansion of fish meal demand under various management schemes. Model projections suggested that regional stocks could recover from climate-driven fluctuations, but only if increased fish meal demand and sub-optimal management did not occur simultaneously. As demand for fish meal and oil are increasing (Tacon \& Metian 2015) and suboptimal management of fisheries worldwide is a continuing challenge (World Bank 2015, Vivekanandan et al. 2016), fisheries decline cannot be ruled out.

Climate change influences on micro-algae, either as a direct food source or indirectly through food webs (Doney 2006), may have major implications for some types of aquaculture. Micro-algae (phytoplankton) are commonly used as feed for cultured finfish larvae (through zooplankton), bivalve molluscs, and crustaceans (Wikfors \& Ohno 2001). On a global scale, the production of major non-fed species contributed $30.7 \%$ by weight to world food fish aquaculture production in 2013 and consisted mainly of filterfeeding bivalves and carps, with $14 \mathrm{Mt}$ of bivalves cultured in marine systems (FAO 2015).

Phytoplankton species account for less than $1 \%$ of the Earth's photosynthetic biomass, but contribute approximately $50 \%$ of the global carbon biogenic fixation (Field et al. 1998), with the global population replaced, on average, every 2 to 6 d (Falkowski et al. 1998, Behrenfeld et al. 2006). Warmer and more stratified oceans are expected to shift phytoplankton communities towards smaller sizes with reduced adaptive capacity (Acevedo-Trejos et al. 2014) and to shift cold-water species' ranges poleward (Hallegraeff 2010). The increase in global sea surface temperatures is also projected to reduce phytoplankton abundance in tropical and mid-latitude regions, while there may be greater phytoplankton abundance in higher-latitude regions. This is because tropical areas are typically nutrient-limited, whereas polar areas are typically light-limited (Richardson \& Schoeman 2004, Doney 2006). However, impacts will vary with location (Doney 2006), possibly benefitting filter-feeding species of shellfish aquaculture in currently nutrient-limited areas (De Silva \& Soto 2009). Some micro-algae can form harmful algal blooms, which are toxic to aquaculture species or which have impacts for human consumption, but the effects of climate change on the severity and frequency of these blooms is uncertain (Wells \& Trainer 2016). Nevertheless, El Niño events have been linked to massive harmful algal blooms in Chile in 2015 and 2016, and, in combination with extreme heat and low dissolved oxygen, impacted Central American tilapia production (Soto et al. 2018). Climate change effects on 'green water' for fish ponds have also warranted consideration. Takarina et al. (2017) reported that during peak high temperatures and consequent oxygen decline in west Java fish ponds, the phytoplankton population was significantly reduced, but not the diversity. There may be qualitative effects to phytoplankton diets as well. Climate warming is predicted to reduce n-3 long-chain, polyunsaturated fatty acid production in micro-algae (Hixson \& Arts 2016).

Data on ocean acidification effects on nutrition are limited, although there has been some suggestion that increased dietary demand by the larval stages of some species under future $\mathrm{pH}$ conditions may be affected. Acidified conditions may compromise the feeding energetics of the sea urchin Strongylocentro- 
tus droebachiensis. Larvae exposed to seawater with lower $\mathrm{pH}$ had lower gastric $\mathrm{pH}$, leading to reduced digestive efficiencies and higher food consumption (Stumpp et al. 2013).

The cost of feed is one of the largest expenses for fed aquaculture production, and dynamics that affect the availability of key ingredients, like fish meal, have greater potential to influence overall production costs. Climate change is expected to further complicate this relationship between aquaculture and climate-sensitive reduction fisheries. While the source materials used to generate ingredients for feed production varies by culture species, the impact of climate change may make traditional sources more challenging to obtain. Fortunately, research on alternate ingredients has been undertaken for many decades, often driven by reductions in periodic availability of fishmeal and fish oil brought about by episodic large-scale oceanic conditions (e.g. El Niño), irrespective of climate change. However, non-fed species typically source food in the local environment and are arguably more vulnerable to climate change if local dietary sources are affected.

\section{CONCLUSIONS}

Information specific to climate change and aquaculture is still in its infancy, but there have been exponential increases in climate change publications in areas of importance to aquaculture. Summarizing relevant global research and reports, with vast differences in regional environments, culture systems, and species, in combination with uncertainties of effects, is not trivial. However, there are some recurring trends and generalities that may have application across the aquaculture spectrum. These are as follows:

(1) The heavy reliance of most global aquaculture on the ambient environment and ecosystem services suggests inherent vulnerability to climate change effects.

(2) Biological response to climate change stressors between related species or even between populations of the same species is not universal.

(3) The magnitude of response, whether positive or negative, as well as negligible responses of a species or population to changes in the climate system, will be a function of:

(a) where changes occur relative to optimal ranges and tolerance limits of an organism's life stage and physiological processes

(b) the average magnitude and duration of the stressor over the production cycle (c) stressor rate of change

(d) variation, frequency, duration, and magnitude of extremes

(e) interaction with other stressors

(f) organism capacity for epigenetic expression or plasticity

(g) genetic strain and population variation

(h) diet quality and quantity

(4) Multiple climate change stressors will occur together and frequently interact. Interaction may not be fully additive or linear but may be synergistic, and one dominant driver may have the greatest effect depending on species and life stage.

(5) There is some potential for epigenetic or short-term acclimation to climate change stressors, but this has not been well quantified or qualified for most aquaculture species and populations. For some species:

(a) Exposure to environmental stressors during early rearing may have a major influence on successful adaptation to similar or different stressors in later life stages.

(b) Parental exposure to environmental change may influence the adaptation potential of offspring.

(6) Climate change may affect plant, algal, and animal health through the host, and/or infectious agents, with uncertain, but potentially profound, outcomes.

(7) Some aquaculture practices (current and previous) may inadvertently reduce resilience to climate change, such as:

(a) reducing coastal protection through historical removal of coastal vegetation

(b) increasing the rate of ground subsidence (lowering) through pumping

(c) reducing genetic variably through domestication in pursuit of consistent production traits, which may impact acclimation and adaptation to climate stressors

(8) Higher production costs at aquaculture operations could be an expected economic impact of climate change for many aquaculture sectors.

(9) Climate change is apt to add additional complexity to the sourcing of ingredients for aquafeeds and affect phytoplankton dynamics for marine filter feeders.

(10) Competition for freshwater resources is apt to be augmented under climate change.

There are gaps in knowledge and/or data accessibility on climate change effects for large portions or world aquaculture, and these form 2 potential limitations of this review. The first limitation is that this review draws primarily upon the scientific English language literature, which is heavily focussed on marine systems in developed regions. As such, this 
review may not be fully reflective of large segments of world aquaculture production. The second limitation is that aquaculture research on the top 3 globally produced species by weight is not well represented in the climate change literature. Grass carp Ctenopharyngodon idellus, silver carp Hypophthalmichthys molitrix, and common carp Cyprinus carpio contribute to $29 \%$ of global aquaculture production (FAO 2018a). These species are heavily produced, in part, due to their resilience and versatility. This robustness reflects their success as invasive species and difficulties eradicating them from novel habitats (e.g. Crichigno et al. 2016, Weber et al. 2016, Erickson et al. 2018, Prechtel et al. 2018), suggesting some potential for tolerance to multiple stressors. Nevertheless, potential resistance to climate change stressors would benefit from explicit quantification in these species to better support planned adaptation for such a large portion of world aquaculture.

Various aquaculture sectors are already being affected by climate change, and greater effects are anticipated. Global-scale consideration of the differences, commonalities, and knowledge gaps of biological responses and resource effects from climate change stressors can guide pragmatic focus on specific aquaculture sectors to better anticipate consequences and prioritize response efforts.

Acknowledgements. Thank-you to the Canadian Integrated Multi-Trophic Aquaculture Network, a strategic network of the Natural Sciences and Engineering Research Council of Canada.

\section{LITERATURE CITED}

69 News (2014) Trout killed by flooding at Allentown fish nursery. www.wfmz.com/news/insideyourtown/trout-killedby-flooding-at-allentown-fish-nursery/article_08afd5cebade-5959-827b-7fe957260b70.html (accessed 30 March 2017)

Abass NY, Elwakil HE, Hemeida AA, Abdelsalam NR and others (2016) Genotype-environment interactions for survival at low and sub-zero temperatures at varying salinity for channel catfish, hybrid catfish and transgenic channel catfish. Aquaculture 458:140-148

Acevedo-Trejos E, Brandt G, Steinacher M, Merico A (2014) A glimpse into the future composition of marine phytoplankton communities. Front Mar Sci 1:1-12

Adelsman H, Whitely Binder L, Chadsey M (2012) Washington State Blue Ribbon Panel on Ocean Acidification: from knowledge to action: Washington State's strategic response. Publication no. 12-01-015. Washington Department of Ecology, Olympia, WA

Adhikari S, Chaudhury AK, Gangadhar B, Ramesh R and others (2018) Adaptation and mitigation strategies of climate change impact in freshwater aquaculture in some states of India. J FisheriesSciences.com 12:016-021
Ahmed N (2013) Climate change impacts on human health in freshwater prawn farming communities in Bangladesh. Aquacult Mag 44:28-43

Ahn IY, Lopez G, Malouf R (1993) Effects of the gem clam Gemma gemma on early post-settlement emigration, growth and survival of the hard clam Mercenaria mercenaria. Mar Ecol Prog Ser 99:61-70

Ahnelt H, Schade FM, Wegner M (2016) Ocean acidification leads to deformations of caudal vein angio-architecture in juvenile threespine stickleback, Gasterosteus aculeatus Linnaeus. J Fish Dis 39:1001-1005

Alfieri L, Feyen L, Dottori F, Bianchi A (2015) Ensemble flood risk assessment in Europe under high end climate scenarios. Glob Environ Change 35:199-212

Allendorf FW, Phelps SR (1980) Loss of genetic variation in a hatchery stock of cutthroat trout. Trans Am Fish Soc 109: 537-543

Allison EH, Perry AL, Badjeck MC, Adger WN and others (2009) Vulnerability of national economies to the impacts of climate change on fisheries. Fish Fish 10:173-196

Allison EH, Badjeck MC, Meinhold K (2011) The implications of global climate change for molluscan aquaculture. In: Shumway SE (ed) Shellfish aquaculture and the environment. Wiley-Blackwell, Singapore, p 461-490

Altizer S, Ostfeld RS, Johnson PTJ, Kutz S, Harvell CD (2013) Climate change and infectious diseases: from evidence to a predictive framework. Science 341:514-519

Álvarez-Salgado XA， Labarta U, Fernández-Reiriz MJ, Figueiras FG and others (2008) Renewal time and the impact of harmful algal blooms on the extensive mussel raft culture of the Iberian coastal upwelling system (SW Europe). Harmful Algae 7:849-855

Amin MN, Barnes RK, Adams LR (2014) Effect of temperature and varying level of carbohydrate and lipid on growth, feed efficiency and nutrient digestibility of brook trout, Salvelinus fontinalis (Mitchill, 1814). Anim Feed Sci Technol 193:111-123

Anderson K, Swanson P, Pankhurst N, King H, Elizur A (2012) Effect of thermal challenge on plasma gonadotropin levels and ovarian steroidogenesis in female maiden and repeat spawning Tasmanian Atlantic salmon (Salmo salar). Aquaculture 334-337:205-212

Anon (2013) Climate change gives fish a boost. Aquaculture North America 4(2):6

* Arkema KK, Guannel G, Verutes G, Wood SA and others (2013) Coastal habitats shield people and property from sea-level rise and storms. Nat Clim Change 3: 913-918

Báez VH, Aigo JD, Cussac VE (2011) Climate change and fish culture in Patagonia: present situation and perspectives. Aquacult Res 42:787-796

*Baker AC, Glynn PW, Riegl B (2008) Climate change and coral reef bleaching: an ecological assessment of longterm impacts, recovery trends and future outlook. Estuar Coast Shelf Sci 80:435-471

* Barange M, Merino G, Blanchard JL, Scholtens J and others (2014) Impacts of climate change on marine ecosystem production in societies dependent on fisheries. Nat Clim Change 4:211-216

* Barnes R, King H, Carter CG (2011) Hypoxia tolerance and oxygen regulation in Atlantic salmon, Salmo salar from a Tasmanian population. Aquaculture 318:397-401

* Barton A, Hales B, Waldbusser G, Langdon C, Feely RA (2012) The Pacific oyster, Crassostrea gigas, shows negative correlation to naturally elevated carbon dioxide lev- 
els: implications for near-term ocean acidification effects. Limnol Oceanogr 57:698-710

Baumann H, Doherty O (2013) Decadal changes in the world's coastal latitudinal temperature gradients. PLOS ONE 8:e67596

Beardall J, Beer S, Raven J (1998) Biodiversity of marine plants in an era of climate change: some predictions based on physiological performance. Bot Mar 41:113-124

* Behrenfeld MJ, O'Malley RT, Siegel DA, McClain CR and others (2006) Climate-driven trends in contemporary ocean productivity. Nature 444:752-755

Bell J, Batty M, Ganachaud A, Gehrke P and others (2009) Preliminary assessment of the effects of climate change on fisheries and aquaculture in the Pacific. In: Gillett $\mathrm{R}$ (ed) Fisheries in the economies of the Pacific Island countries and territories. Pacific Studies Series. Asian Development Bank, Manila, p 451-469

Bell JD, Reid C, Batty MJ, Lehodey P and others (2013) Effects of climate change on oceanic fisheries in the tropical Pacific: implications for economic development and food security. Clim Change 119:199-212

* Beniash E, Ivanina A, Lieb NS, Kurochkin I, Sokolova IM (2010) Elevated level of carbon dioxide affects metabolism and shell formation in oysters Crassostrea virginica. Mar Ecol Prog Ser 419:95-108

Berge JA, Bjerkeng B, Pettersen O, Schaanning MT, Øxnevad S (2006) Effects of increased sea water concentrations of $\mathrm{CO}_{2}$ on growth of the bivalve Mytilus edulis L. Chemosphere 62:681-687

Besson M, Vandeputte M, van Arendonk JAM, Aubin J, de Boer IJM, Quillet E, Komen H (2016) Influence of water temperature on the economic value of growth rate in fish farming: the case of sea bass (Dicentrarchus labrax) cage farming in the Mediterranean. Aquaculture 462:47-55

Bibby R, Widdicombe S, Parry H, Spicer J, Pipe R (2008) Effects of ocean acidification on the immune response of the blue mussel Mytilus edulis. Aquat Biol 2:67-74

Binh MN, Van An L, Thuy NTT, Giang NT, Hoai HTT, Van Dan T (2017) Impact of climate change on aquaculture in Phu Vang District, Thua Thien Hue Province, Vietnam. Agriculture and Development Discussion Paper Series 2017-3. Southeast Asian Regional Center for Graduate Study and Research in Agriculture (SEARCA), Los Baños

Bolstad GH, Hindar K, Robertsen G, Jonsson B and others (2017) Gene flow from domesticated escapes alters the life history of wild Atlantic salmon. Nat Ecol Evol 1:0124

Booth M (2014) Tynehead Hatchery opens doors to public, post flooding. www.thenownewspaper.com/community/ 300244841.html (accessed 28 September 2016)

* Bopp L, Resplandy L, Orr JC, Doney SC and others (2013) Multiple stressors of ocean ecosystems in the 21st century: projections with CMIP5 models. Biogeosciences 10: 6225-6245

Bourdeau PE, Butlin RK, Bronmark C, Edgell TC, Hoverman JT, Hollander J (2015) What can aquatic gastropods tell us about phenotypic plasticity? A review and metaanalysis. Heredity 115:312-321

Bournazel J, Kumara MP, Jayatissa LP, Viergever K, Morel V, Huxham M (2015) The impacts of shrimp farming on land-use and carbon storage around Puttalam lagoon, Sri Lanka. Ocean Coast Manag 113:18-28

* Bowden TJ, Thompson KD, Morgan AL, Gratacap RML, Nikoskelainen S (2007) Seasonal variation and the immune response: a fish perspective. Fish Shellfish Immunol 22:695-706
Boyd PW, Lennartz ST, Glover DM, Doney SC (2015) Biological ramifications of climate-change-mediated oceanic multi-stressors. Nat Clim Change 5:71-79

* Branco PC, Borges JCS, Santos MF, Jensch BE, Silva JRMC (2013) The impact of rising sea temperature on innate immune parameters in the tropical subtidal sea urchin Lytechinus variegatus and the intertidal sea urchin Echinometra lucunter. Mar Environ Res 92:95-101

*Bander K (2013) Climate and current anthropogenic impacts on fisheries. Clim Change 119:9-21

* Brazenor AK, Hutson KS (2013) Effect of temperature and salinity on egg hatching and description of the life cycle of Lernanthropus latis (Copepoda: Lernanthropidae) infecting barramundi, Lates calcarifer. Parasitol Int 62: 437-447

Brennan G, Collins S (2015) Growth responses of a green alga to multiple environmental drivers. Nat Clim Change 5:892-897

* Bresolin de Souza KB, Jutfelt F, Kling P, Förlin L, Sturve J (2014) Effects of increased $\mathrm{CO}_{2}$ on fish gill and plasma proteome. PLOS ONE 9:e102901

Brinkmann M, Hudjetz S, Kammann U, Hennig M and others (2013) How flood events affect rainbow trout: evidence of a biomarker cascade in rainbow trout after exposure to PAH contaminated sediment suspensions. Aquat Toxicol 128-129:13-24

* Britz PJ, Hecht T, Mangold S (1997) Effect of temperature on growth, feed consumption and nutritional indices of Haliotis midae fed a formulated diet. Aquaculture 152: 191-203

Brooks A (2013) Fish back in the hatchery after June flooding. www.calgaryjournal.ca/index.php/news/1977-fishback-in-the-hatchery-after-june-flooding (accessed 23 September 2016)

Brugère C (2015) Climate change vulnerability in fisheries and aquaculture: a synthesis of six regional studies. FAO Fisheries Circular. FAO, Rome

*Buchheister A, Miller TJ, Houde ED, Secor DH, Latour RJ (2016) Spatial and temporal dynamics of Atlantic menhaden (Brevoortia tyrannus) recruitment in the Northwest Atlantic Ocean. ICES J Mar Sci 73:1147-1159

* Buchtíková S, Šimková A, Rohlenová K, Flajšhans M, Lojek A, Lilius EM, Hyršl P (2011) The seasonal changes in innate immunity of the common carp (Cyprinus carpio). Aquaculture 318:169-175

*Buchwald RT, Feehan CJ, Scheibling RE, Simpson AGB (2015) Low temperature tolerance of a sea urchin pathogen: implications for benthic community dynamics in a warming ocean. J Exp Mar Biol Ecol 469:1-9

* Burge CA, Eakin CM, Friedman CS, Froelich B and others (2014) Climate change influences on marine infectious diseases: implications for management and society. Annu Rev Mar Sci 6:249-277

* Byrne M, Ho M, Selvakumaraswamy P, Nguyen HD, Dworjanyn SA, Davis AR (2009) Temperature, but not $\mathrm{pH}$, compromises sea urchin fertilization and early development under near-future climate change scenarios. Proc R Soc B 276:1883-1888

* Byrne M, Gonzalez-Bernat M, Doo S, Foo S, Soars N, Lamare M (2013) Effects of ocean warming and acidification on embryos and non-calcifying larvae of the invasive sea star Patiriella regularis. Mar Ecol Prog Ser 473: 235-246

Cai W, Borlace S, Lengaigne M, van Rensch P and others (2014) Increasing frequency of extreme El Niño events 
due to greenhouse warming. Nat Clim Change 4: 111-116

Cai W, Wang G, Santoso A, McPhaden MJ and others (2015) Increased frequency of extreme La Niña events under greenhouse warming. Nat Clim Change 5:132-137

Callaway R, Shinn AP, Grenfell SE, Bron JE and others (2012) Review of climate change impacts on marine aquaculture in the UK and Ireland. Aquat Conserv 22:389-421

* Cao R, Wang Q, Yang D, Liu Y and others (2018) $\mathrm{CO}_{2}$ induced ocean acidification impairs the immune function of the Pacific oyster against Vibrio splendidus challenge: an integrated study from a cellular and proteomic perspective. Sci Total Environ 625:1574-1583

* Cazenave A, Dieng HB, Meyssignac B, von Schuckmann K, Decharme B, Berthier E (2014) The rate of sea-level rise. Nat Clim Change 4:358-361

* Chadwick R, Good P, Martin G, Rowell DP (2016) Large rainfall changes consistently projected over substantial areas of tropical land. Nat Clim Change 6:177-181

* Chand SS, Tory KJ, Ye H, Walsh KJE (2017) Projected increase in El Niño-driven tropical cyclone frequency in the Pacific. Nat Clim Change 7:123-127

* Chen CY, Chao CB, Bowser PR (2006) Infection of tilapia Oreochromis sp. by Vibrio vulnificus in freshwater and lowsalinity environments. J World Aquacult Soc 37:82-88

Chiaramonte L, Munson D, Trushenski J (2016) Climate change and considerations for fish health and fish health professionals. Fisheries 41:396-399

Chivers DP, McCormick MI, Nilsson GE, Munday PL and others (2014) Impaired learning of predators and lower prey survival under elevated $\mathrm{CO}_{2}$ : a consequence of neurotransmitter interference. Glob Change Biol 20:515-522

Cho CY, Kaushik SJ (1990) Nutritional energetics in fish: energy and protein utilization in rainbow trout (Salmo gairdneri). In: GH Bourne (ed) Aspects of food production, consumption and energy values. Karger, Basel, p 132-172

Choi HG, Kim YS, Kim JH, Lee SJ, Park EJ, Ryu J, Nam KW (2006) Effects of temperature and salinity on the growth of Gracilaria verrucosa and G. chorda, with the potential for mariculture in Korea. J Appl Phycol 18:269-277

* Choi K, Lehmann DW, Harms CA, Law JM (2007) Acute hypoxia-reperfusion triggers immunocompromise in Nile tilapia. J Aquat Anim Health 19:128-140

Chopin T (2018) To enable Integrated Multi-Trophic Aquaculture (IMTA) and the seaweed sector to develop in Canada, regulatory issues will need to be seriously addressed. Bull Aquacult Assoc Can 2017-1:41-44

Chopin T, Sawhney M (2009) Seaweeds and their mariculture. In: Steele J, Thorpe S, Turekian KK (eds) The encyclopedia of ocean sciences. Elsevier, Oxford, p 317-326

* Chown SL, Hodgins KA, Griffin PC, Oakeshott JG, Byrne M, Hoffmann AA (2015) Biological invasions, climate change and genomics. Evol Appl 8:23-46

Chung WS, Marshall NJ, Watson SA, Munday PL, Nilsson GE (2014) Ocean acidification slows retinal function in a damselfish through interference with GABAA receptors. J Exp Biol 217:323-326

Church JA, Hunter JR, McInnes KL, White NJ (2006) Sealevel rise around the Australian coastline and the changing frequency of extreme sea-level events. Aust Meteorol Mag 55:253-260

Clark TD, Sandblom E, Jutfelt F (2013) Aerobic scope measurements of fishes in an era of climate change: respirometry, relevance and recommendations. J Exp Biol 216: 2771-2782
Cook T, Folli M, Klinck J, Ford S, Miller J (1998) The relationship between increasing sea-surface temperature and the northward spread of Perkinsus marinus (Dermo) disease epizootics in oysters. Estuar Coast Shelf Sci 46: 587-597

Cornelisen CD, Gillespie PA, Kirs M, Young RG and others (2011) Motueka River plume facilitates transport of ruminant faecal contaminants into shellfish growing waters, Tasman Bay, New Zealand. NZ J Mar Freshw Res 45: 477-495

Costa-Pierce BA, Bartley DM, Hasan M, Yusoff F and others (2011) Responsible use of resources for sustainable aquaculture. Global Conference on Aquaculture 2010, Sept. 22-25, 2010, Phuket, Thailand. FAO, Rome, p 38

Costello MJ (2009) The global economic cost of sea lice to the salmonid farming industry. J Fish Dis 32:115-118

Cottier-Cook EJ, Nagabhatla N, Badis Y, Campbell ML and others (2016) Safeguarding the future of the global seaweed aquaculture industry. United Nations University (INWEH) and Scottish Association for Marine Science Policy Brief. https://inweh.unu.edu/wp-content/uploads/ 2016/09/unu-seaweed-aquaculture-policy.pdf

* Crichigno S, Cordero P, Blasetti G, Cussac V (2016) Dispersion of the invasive common carp Cyprinus carpio in southern South America: changes and expectations, westward and southward. J Fish Biol 89:403-416

C Crozier LG, Hutchings JA (2014) Plastic and evolutionary responses to climate change in fish. Evol Appl 7:68-87

* Currie KL, Lange B, Herbert EW, Harris JO, Stone DAJ (2015) Gastrointestinal evacuation time, but not nutrient digestibility, of greenlip abalone, Haliotis laevigata Donovan, is affected by water temperature and age. Aquaculture 448:219-228

Dabbadie L, Aguilar-Manjarrez J, Beveridge MCM, Bueno PB, Ross LG, Soto D (2018) Effects of climate change on aquaculture: drivers, impacts and policies. In: Barange M, Bahri T, Beveridge MCM, Cochrane KL, Funge-Smith $\mathrm{S}$, Poulain Fe (eds) Impacts of climate change on fisheries and aquaculture. FAO, Rome, p 449-463

* Damsgaard C, Gam LTH, Tuong DD, Thinh PV, Huong Thanh DT, Wang T, Bayley M (2015) High capacity for extracellular acid-base regulation in the air-breathing fish Pangasianodon hypophthalmus. J Exp Biol 218: 1290

*Das S, Mangwani N (2015) Ocean acidification and marine microorganisms: responses and consequences. Oceanologia 57:349-361

* Das SK, Murmu K, Das A, Shakuntala I, Das RK, Ngachan SV, Majhi SK (2012) Studies on the identification and control of pathogen Saprolegnia in selected Indian major carp fingerlings at mid hill altitude. J Environ Biol 33: 545-549

Daw T, Adger WN, Brown K, Badjeck MC (2009) Climate change implications for fisheries and aquaculture: overview of current scientific knowledge. In: Cochrane K, De Young C, Soto D, Bahri T (eds) Climate change implications for fisheries and aquaculture: overview of current scientific knowledge. Fish Aquacult Tech Pap 530. FAO, Rome, p 107-150

* De Silva SS (2016) Culture based fisheries in Asia are a strategy to augment food security. Food Secur 8:585-596

De Silva SS, Soto D (2009) Climate change and aquaculture: potential impacts, adaptation and mitigation. In: Cochrane K, De Young C, Soto D, Bahri T (eds) Climate change implications for fisheries and aquaculture: over- 
view of current scientific knowledge. Fish Aquacult Tech Pap 530. FAO, Rome, p 151-212

DePasquale E, Baumann H, Gobler CJ (2015) Vulnerability of early life stage Northwest Atlantic forage fish to ocean acidification and low oxygen. Mar Ecol Prog Ser 523: 145-156

Dey MM, Gosh K, Valmonte-Santos R, Rosegrant MW, Chen OL (2016) Economic impact of climate change and climate change adaptation strategies for fisheries sector in Fiji. Mar Policy 67:164-170

Di Lorenzo E, Schneider N, Cobb K, Franks P and others (2008) North Pacific Gyre Oscillation links ocean climate and ecosystem change. Geophys Res Lett 35:L0860

* Díaz RJ, Rosenberg R, Rabalais NN, Levin LA (2009) Dead zone dilemma. Mar Pollut Bull 58:1767-1768

Widar-Ul Islam SM, Bhuiyan MAH (2016) Impact scenarios of shrimp farming in coastal region of Bangladesh: an approach of an ecological model for sustainable management. Aquacult Int 24:1163-1190

"Dineshram R, Wong KKW, Xiao S, Yu Z, Qian PY, Thiyagarajan V (2012) Analysis of Pacific oyster larval proteome and its response to high- $\mathrm{CO}_{2}$. Mar Pollut Bull 64: 2160-2167

Dodd Q (2013) \$30 million to resolve Idaho water rights. Aquaculture North America 4(1):23

Doney SC (2006) Plankton in a warmer world. Nature 444: 695-696

Dulvy N, Allison E (2009) A place at the table? Nat Clim Change 3:68-70

Dupont S, Dorey N, Stumpp M, Melzner F, Thorndyke M (2013) Long-term and trans-life-cycle effects of exposure to ocean acidification in the green sea urchin Strongylocentrotus droebachiensis. Mar Biol 160:1835-1843

* Durack PJ, Gleckler PJ, Landerer FW, Taylor KE (2014) Quantifying underestimates of long-term upper-ocean warming. Nat Clim Change 4:999-1005

Eakin CM, Morgan JA, Heron SF, Smith TB and others (2010) Caribbean corals in crisis: record thermal stress, bleaching, and mortality in 2005. PLOS ONE 5:e13969

Ekstrom JA, Suatoni L, Cooley SR, Pendleton LH and others (2015) Vulnerability and adaptation of US shellfisheries to ocean acidification. Nat Clim Change 5:207-214

Ellis RP, Urbina MA, Wilson RW (2017) Lessons from two high $\mathrm{CO}_{2}$ worlds - future oceans and intensive aquaculture. Glob Change Biol 23:2141-2148

Emerson CE, Reinardy HC, Bates NR, Bodnar AG (2017) Ocean acidification impacts spine integrity but not regenerative capacity of spines and tube feet in adult sea urchins. R Soc Open Sci 4:170140

E Erickson RA, Eager EA, Kocovsky PM, Glover DC, Kallis JL, Long KR (2018) A spatially discrete, integral projection model and its application to invasive carp. Ecol Model 387:163-171

Evans TG, Padilla-Gamiño JL, Kelly MW, Pespeni MH and others (2015) Ocean acidification research in the 'postgenomic' era: roadmaps from the purple sea urchin Strongylocentrotus purpuratus. Comp Biochem Physiol A Mol Integr Physiol 185:33-42

Falkowski PG, Barber RT, Smetacek V (1998) Biogeochemical controls and feedbacks on ocean primary production. Science 281:200-206

FAO (2007) The world's mangroves 1980-2005. FAO, Rome

FAO (2014) The state of world fisheries and aquaculture: opportunities and challenges. Rep 1020-5489. FAO, Rome
FAO (2015) Global aquaculture production statistics database updated to 2013-summary information. FAO, Rome

FAO (2016) The state of the world fisheries and aquaculture 2016: contributing to food security and nutrition for all. FAO, Rome

FAO (2018a) The state of world fisheries and aquaculture 2018: meeting the sustainable development goals. FAO, Rome

FAO (2018b) FAO's work on climate change. FAO, Rome

* Fassbender AJ, Sabine CL, Feifel KM (2016) Consideration of coastal carbonate chemistry in understanding biological calcification. Geophys Res Lett 43:4467-4476

Fearman J, Moltschaniwskyj NA (2010) Warmer temperatures reduce rates of gametogenesis in temperate mussels, Mytilus galloprovincialis. Aquaculture 305:20-25

Field CB, Behrenfeld MJ, Randerson JT, Falkowski P (1998) Primary production of the biosphere: integrating terrestrial and oceanic components. Science 281: 237-240

Floyd M (2016) Five years after tsunami, scientists cross fingers on invasive species establishment. https://today. oregonstate.edu/archives/2016/mar/five-years-aftertsunami-scientists-cross-fingers-invasive-species-establishment.html

Freitas R, De Marchi L, Bastos M, Moreira A and others (2017) Effects of seawater acidification and salinity alterations on metabolic, osmoregulation and oxidative stress markers in Mytilus galloprovincialis. Ecol Indic 79: 54-62

Froehlich HE, Gentry RR, Halpern BS (2016) Synthesis and comparative analysis of physiological tolerance and lifehistory growth traits of marine aquaculture species. Aquaculture 460:75-82

*Frommel AY, Maneja R, Lowe D, Malzahn AM and others (2012) Severe tissue damage in Atlantic cod larvae under increasing ocean acidification. Nat Clim Change 2:42-46

* Frommel AY, Maneja R, Lowe D, Pascoe CK and others (2014) Organ damage in Atlantic herring larvae as a result of ocean acidification. Ecol Appl 24:1131-1143

Fry FEJ, Hart JS (1948) The relation of temperature to oxygen consumption in the goldfish. Biol Bull (Woods Hole) 94:66-77

Funari E, Manganelli M, Sinisi L (2012) Impact of climate change on waterborne diseases. Ann Ist Super Sanita 48: 473-487

Gaitán-Espitia JD, Marshall D, Dupont S, Bacigalupe LD, Bodrossy L, Hobday AJ (2017) Geographical gradients in selection can reveal genetic constraints for evolutionary responses to ocean acidification. Biol Lett 13:20160784

Garilli V, Rodolfo-Metalpa R, Scuderi D, Brusca L and others (2015) Physiological advantages of dwarfing in surviving extinctions in high- $\mathrm{CO}_{2}$ oceans. Nat Clim Change 5: $678-682$

* Gavery MR, Roberts SB (2017) Epigenetic considerations in aquaculture. PeerJ 5:e4147

Gavery MR, Nichols KM, Goetz GW, Middleton MA, Swanson P (2018) Characterization of genetic and epigenetic variation in sperm and red blood cells from adult hatchery and natural-origin steelhead, Oncorhynchus mykiss. Genes Genomes Genet 8:3723-3736

Gaylord B, Hill TM, Sanford E, Lenz EA and others (2011) Functional impacts of ocean acidification in an ecologically critical foundation species. J Exp Biol 214: 2586-2594 
Gaylord B, Kroeker KJ, Sunday JM, Anderson KM and others (2015) Ocean acidification through the lens of ecological theory. Ecology 96:3-15

*Gazeau F, Quiblier C, Jansen JM, Gattuso JP, Middelburg JJ, Heip CHR (2007) Impact of elevated $\mathrm{CO}_{2}$ on shellfish calcification. Geophys Res Lett 34:L07603

Gazeau F, Gattuso JP, Dawber C, Pronker AE and others (2010) Effect of ocean acidification on the early life stages of the blue mussel Mytilus edulis. Biogeosciences 7:2051-2060

Gazeau F, Parker LM, Comeau S, Gattuso JP and others (2013) Impacts of ocean acidification on marine shelled molluscs. Mar Biol 160:2207-2245

* Gentry RR, Froehlich HE, Grimm D, Kareiva P and others (2017) Mapping the global potential for marine aquaculture. Nat Ecol Evol 1:1317-1324

Giri C, Zhu Z, Tieszen LL, Singh A, Gillette S, Kelmelis JA (2008) Mangrove forest distributions and dynamics (19752005) of the tsunami-affected region of Asia. J Biogeogr 35:519-528

Glencross B, Bermudes M (2010) Effect of high water temperatures on the utilisation efficiencies of energy and protein by juvenile barramundi, Lates calcarifer. Fish Aquac J 2010:FAJ-14

Glencross BD, Bermudes M (2012) Adapting bioenergetic factorial modelling to understand the implications of heat stress on barramundi (Lates calcarifer) growth, feed utilisation and optimal protein and energy requirements potential strategies for dealing with climate change? Aquacult Nutr 18:411-422

Glencross BD, Booth M, Allan GL (2007) A feed is only as good as its ingredients - a review of ingredient evaluation strategies for aquaculture feeds. Aquacult Nutr 13: $17-34$

GlobalAgRisk (2012) Extreme El Niño insurance for climate change prevention and adaptation in Peru. Insurance for Climate Change Adaptation Project Technical Note 2, Rep 2012-09516. National Library of Peru, Lima

Gobler CJ, Baumann H (2016) Hypoxia and acidification in ocean ecosystems: coupled dynamics and effects on marine life. Biol Lett 12:20150976

Gobler CJ, Talmage SC (2013) Short- and long-term consequences of larval stage exposure to constantly and ephemerally elevated carbon dioxide for marine bivalve populations. Biogeosciences 10:2241-2253

Gobler CJ, DePasquale EL, Griffith AW, Baumann H (2014) Hypoxia and acidification have additive and synergistic negative effects on the growth, survival, and metamorphosis of early life stage bivalves. PLOS ONE 9:e83648

Graiff A, Bartsch I, Ruth W, Wahl M, Karsten U (2015) Season exerts differential effects of ocean acidification and warming on growth and carbon metabolism of the seaweed Fucus vesiculosus in the western Baltic Sea. Front Mar Sci 2:112

* Gräns A, Jutfelt F, Sandblom E, Jönsson E and others (2014) Aerobic scope fails to explain the detrimental effects on growth resulting from warming and elevated $\mathrm{CO}_{2}$ in Atlantic halibut. J Exp Biol 217:711-717

Green MA, Waldbusser GG, Reilly SL, Emerson K, O'Donnell S (2009) Death by dissolution: sediment saturation state as a mortality factor for juvenile bivalves. Limnol Oceanogr 54:1037-1047

Groner ML, Gettinby G, Stormoen M, Revie CW, Cox R (2014) Modelling the impact of temperature-induced life history plasticity and mate limitation on the epidemic potential of a marine ectoparasite. PLOS ONE 9:e88465 *Groner ML, McEwan GF, Rees EE, Gettinby G, Revie CW (2016) Quantifying the influence of salinity and temperature on the population dynamics of a marine ectoparasite. Can J Fish Aquat Sci 73:1281-1291

Gubbins M, Bricknell I, Service M (2013) Impacts of climate change on aquaculture. MCCIP Sci Rev 2013:318-327

Guevara-Fletcher C, Alvarez P, Sanchez J, Iglesias J (2016) Effect of temperature on the development and mortality of European hake (Merluccius merluccius L.) eggs from southern stock under laboratory conditions. J Exp Mar Biol Ecol 476:50-57

Gurney-Smith HJ, Wade AJ, Abbott CL (2017) Species composition and genetic diversity of farmed mussels in British Columbia, Canada. Aquaculture 466:33-40

* Guzmán-Agüero JE, Nieves-Soto M, Angel Hurtado M, Pina-Valdez P, del Carmen Garza-Aguirre M (2013) Feeding physiology and scope for growth of the oyster Crassostrea corteziensis (Hertlein, 1951) acclimated to different conditions of temperature and salinity. Aquacult Int 21:283-297

*Hallegraeff GM (2010) Ocean climate change, phytoplankton community responses, and harmful algal blooms: a formidable predictive challenge. J Phycol 46:220-235

*Hamilton S (2013) Assessing the role of commercial aquaculture in displacing mangrove forest. Bull Mar Sci 89: 585-601

* Hamilton TJ, Holcombe A, Tresguerres M (2014) $\mathrm{CO}_{2}$ induced ocean acidification increases anxiety in rockfish via alteration of GABAA receptor functioning. Proc R Soc B 281:20132509

Handisyde N, Salam MA, Ross LG (2008) Spatial aspects of climate change and effects on aquaculture in Bangladesh. 29th Asian Conference on Remote Sensing 2008, Colombo, Vol 2. Elsevier, Amsterdam, p 848-854

*Handisyde N, Telfer TC, Ross LG (2017) Vulnerability of aquaculture-related livelihoods to changing climate at the global scale. Fish Fish 18:466-488

Hargreaves JA (2014) Editor's note: Climate change is here now. Aquacult Mag 45:3

* Harkes IHT, Drengstig A, Kumara MP, Jayasinghe JMPK, Huxham M (2015) Shrimp aquaculture as a vehicle for climate compatible development in Sri Lanka. The case of Puttalam Lagoon. Mar Policy 61:273-283

*Harvell CD, Mitchell CE, Ward JR, Altizer S, Dobson AP, Ostfeld RS, Samuel MD (2002) Climate warming and disease risks for terrestrial and marine biota. Science 296: 2158-2162

*Hauber ME, Bierbach D, Linsenmair KE (2011) The traditional Whedo aquaculture system in northern Benin. J Appl Aquacult 23:67-84

*Haunschild R, Bornmann L, Marx W (2016) Climate change research in view of bibliometrics. PLOS ONE 11: e0160393

*Hay CC, Morrow E, Kopp RE, Mitrovica JX (2015) Probabilistic reanalysis of twentieth-century sea-level rise. Nature 517:481-484

* Hennon GMM, Ashworth J, Groussman RD, Berthiaume C and others (2015) Diatom acclimation to elevated $\mathrm{CO}_{2}$ via cAMP signalling and coordinated gene expression. Nat Clim Change 5:761-765

*Hepburn CD, Pritchard DW, Cornwall CE, McLeod RJ, Beardall J, Raven JA, Hurd CL (2011) Diversity of carbon use strategies in a kelp forest community: implications for a high $\mathrm{CO}_{2}$ ocean. Glob Change Biol 17:2488-2497 
Herbeck LS, Unger D, Wu Y, Jennerjahn TC (2013) Effluent, nutrient and organic matter export from shrimp and fish ponds causing eutrophication in coastal and back-reef waters of NE Hainan, tropical China. Cont Shelf Res 57: 92-104

Hermansen O, Heen K (2012) Norwegian salmonid farming and global warming: socioeconomic impacts. Aquac Econ Manag 16:202-221

*Hernandez-Llamas A, Zarain-Herzberg M (2011) Bioeconomic modeling and risk analysis of raising shrimp Litopenaeus vannamei in floating cages in northwestern Mexico: assessment of hurricane hazard, stochastic variability of shrimp and feed prices, and zootechnical parameters. Aquaculture 314:261-268

* Hernroth B, Sköld HN, Wiklander K, Jutfelt F, Baden S (2012) Simulated climate change causes immune suppression and protein damage in the crustacean Nephrops norvegicus. Fish Shellfish Immunol 33:1095-1101

Hernroth B, Baden S, Tassidis H, Hörnaeus K, Guillemant J, Bergström Lind S, Bergquist J (2016) Impact of ocean acidification on antimicrobial activity in gills of the blue mussel (Mytilus edulis). Fish Shellfish Immunol 55: 452-459

Hettinger A, Sanford E, Gaylord B, Hill TM, Russell AD (2012) Extended larval carry-over effects: synergisms from a stressful benthic existence in juvenile Olympia oysters. J Shellfish Res 31:296

Hettinger A, Sanford E, Hill TM, Hosfelt JD, Russell AD, Gaylord B (2013) The influence of food supply on the response of Olympia oyster larvae to ocean acidification. Biogeosciences 10:6629-6638

*Higgins S, Overeem I, Tanaka A, Syvitski JPM (2013) Land subsidence at aquaculture facilities in the Yellow River delta, China. Geophys Res Lett 40:3898-3902

*Hirabayashi Y, Mahendran R, Koirala S, Konoshima L and others (2013) Global flood risk under climate change. Nat Clim Change 3:816-821

Hixson SM, Arts MT (2016) Climate warming is predicted to reduce omega-3, long-chain, polyunsaturated fatty acid production in phytoplankton. Glob Change Biol 22: 2744-2755

HLPE (High Level Panel of Experts on Food Security and Nutrition) (2014) Sustainable fisheries and aquaculture for food security and nutrition. HLPE, Rome

Hobday AJ, Spillman CM, Eveson JP, Hartog JR, Zhang X, Brodie S (2018) A framework for combining seasonal forecasts and climate projections to aid risk management for fisheries and aquaculture. Front Mar Sci 5:137

Hoffmann AA, Sgro CM (2011) Climate change and evolutionary adaptation. Nature 470:479-485

Kofmann GE, Barry JP, Edmunds PJ, Gates RD, Hutchins DA, Klinger T, Sewell MA (2010) The effect of ocean acidification on calcifying organisms in marine ecosystems: an organism-to-ecosystem perspective. Annu Rev Ecol Evol Syst 41:127-147

Holding JM, Duarte CM, Sanz-Martin M, Mesa E and others (2015) Temperature dependence of $\mathrm{CO}_{2}$-enhanced primary production in the European Arctic Ocean. Nat Clim Change 5:1079-1082

Holst R, Yu X (2010) Climate change and production risk in Chinese aquaculture. IATRC Public Trade Policy Research and Analysis Symposium, 'Climate Change in World Agriculture: Mitigation, Adaptation, Trade and Food Security', June 27-29, 2010, Universität Hohenheim, Stuttgart
Hoque MA, Scheelbeek PFD, Vineis P, Khan AE, Ahmed KM, Butler AP (2016) Drinking water vulnerability to climate change and alternatives for adaptation in coastal South and South East Asia. Clim Change 136: 247-263

Hori TS, Gamperl AK, Nash G, Booman M, Barat A, Rise ML (2013) The impact of a moderate chronic temperature increase on spleen immune-relevant gene transcription depends on whether Atlantic cod (Gadus morhua) are stimulated with bacterial versus viral antigens. Genome 56:567-576

*Howes E, Joos F, Eakin M, Gattuso JP (2015) An updated synthesis of the observed and projected impacts of climate change on the chemical, physical and biological processes in the oceans. Front Mar Sci 2:36

Hua K, Bureau DP (2009) Development of a model to estimate digestible lipid content of salmonid fish feeds. Aquaculture 286:271-276

Huguet CT, Norambuena F, Emery JA, Hermon K, Turchini GM (2015) Dietary n-6/n-3 LC-PUFA ratio, temperature and time interactions on nutrients and fatty acids digestibility in Atlantic salmon. Aquaculture 436:160-166

*Hui W, Guodong L, Jiahui L, Hongshuai Y, Jun Q, Pao X (2015) Combined effects of temperature and salinity on yolk utilization in Nile tilapia (Oreochromis niloticus). Aquacult Res 46:2418-2425

Idris K, Azman A, D'Silva JL, Man N, Shaffril HAM (2014) Environmental challenges on aquaculture rearing in Malaysia: the views of brackish-water cage entrepreneurs in Malaysia. Life Sci J 11:509-513

IPCC (2007) Climate Change 2007: the physical science basis. Contribution of Working Group I to the Fourth Assessment Report of the Intergovernmental Panel on Climate Change. Cambridge University Press, Cambridge

IPCC (2013) Summary for policymakers. In: Socker TF, Qin D, Plattner GK, Tignor M and others (eds) Climate change 2013: the physical science basis. Contribution of Working Group I to the Fifth Assessment Report of the Intergovernmental Panel on Climate Change. Cambridge University Press, Cambridge, p 3-33

Ivanina AV, Dickinson GH, Matoo OB, Bagwe R, Dickinson A, Beniash E, Sokolova IM (2013) Interactive effects of elevated temperature and $\mathrm{CO}_{2}$ levels on energy metabolism and biomineralization of marine bivalves Crassostrea virginica and Mercenaria mercenaria. Comp Biochem Physiol A Mol Integr Physiol 166:101-111

* Jansson A, Norkko J, Norkko A (2013) Effects of reduced pH on Macoma balthica larvae from a system with naturally fluctuating pH-dynamics. PLOS ONE 8:e68198

Jensen $\varnothing$, Dempster T, Thorstad EB, Uglem I, Fredheim A (2010) Escapes of fishes from Norwegian sea-cage aquaculture: causes, consequences and prevention. Aquacult Environ Interact 1:71-83

Johnson B (2011) Cherokee fish hatchery digs out after flash flood. www.smokymountainnews.com/news/item/4518cherokee-fish-hatchery-digs-out-after-flash-flood (accessed 16 December 2015)

Kais SM, Islam MS (2018) Impacts of and resilience to climate change at the bottom of the shrimp commodity chain in Bangladesh: a preliminary investigation. Aquaculture 493:406-415

Kam SP, Badjeck MC, Teh L, Tran N (2012) Autonomous adaptation to climate change by shrimp and catfish farmers in Vietnam's Mekong River delta. WorldFish, Penang Karim M, Castine S, Brooks A, Beare D, Beveridge M, 
Phillips M (2014) Asset or liability? Aquaculture in a natural disaster prone area. Ocean Coast Manag 96: 188-197

Karvonen A, Rintamaki P, Jokela J, Valtonen ET (2010) Increasing water temperature and disease risks in aquatic systems: climate change increases the risk of some, but not all, diseases. Int J Parasitol 40:1483-1488

Kautsky N, Rönnbäck P, Tedengren M, Troell M (2000) Ecosystem perspectives on management of disease in shrimp pond farming. Aquaculture 191:145-161

Kennedy DA, Kurath G, Brito IL, Purcell MK, Read AF, Winton JR, Wargo AR (2016) Potential drivers of virulence evolution in aquaculture. Evol Appl 9:344-354

Khan AH, Levac E, Chmura GL (2013) Future sea surface temperatures in Large Marine Ecosystems of the Northwest Atlantic. ICES J Mar Sci 70:915-921

Khan JR, Pether S, Bruce M, Walker SP, Herbert NA (2014) Optimum temperatures for growth and feed conversion in cultured hapuku (Polyprion oxygeneios) - Is there a link to aerobic metabolic scope and final temperature preference? Aquaculture 430:107-113

King JR, Agostini VN, Harvey CJ, McFarlane GA and others (2011) Climate forcing and the California Current ecosystem. ICES J Mar Sci 68:1199-1216

Kipkemboi J, Kilonzi CM, van Dam AA, Kitaka N, Mathooko JM, Denny P (2010) Enhancing the fish production potential of Lake Victoria papyrus wetlands, Kenya, using seasonal flood-dependent ponds. Wetlands Ecol Manag 18:471-483

Kroeker KJ, Kordas RL, Crim RN, Singh GG (2010) Metaanalysis reveals negative yet variable effects of ocean acidification on marine organisms. Ecol Lett 13: 1419-1434

Kroeker KJ, Gaylord B, Hill TM, Hosfelt JD, Miller SH, Sanford $\mathrm{E}$ (2014) The role of temperature in determining species' vulnerability to ocean acidification: a case study using Mytilus galloprovincialis. PLOS ONE 9:e100353

Kurihara H, Kato S, Ishimatsu A (2007) Effects of increased seawater $\mathrm{pCO}_{2}$ on early development of the oyster Crassostrea gigas. Aquat Biol 1:91-98

Kurihara H, Asai T, Kato S, Ishimatsu A (2008) Effects of elevated $\mathrm{pCO}_{2}$ on early development in the mussel Mytilus galloprovincialis. Aquat Biol 4:225-233

*afferty KD, Harvell CD, Conrad JM, Friedman CS and others (2015) Infectious diseases affect marine fisheries and aquaculture economics. Annu Rev Mar Sci 7:471-496

Lawrence C (2016) Substantial damage at WSS fish hatchery after floods. http://wvmetronews.com/2016/07/06/ substantial-damage-at-wss-fish-hatchery-after-floods/ (accessed 1 November 2016)

Leduc AOHC, Munday PL, Brown GE, Ferrari MCO (2013) Effects of acidification on olfactory-mediated behaviour in freshwater and marine ecosystems: a synthesis. Philos Trans R Soc B 368:20120447

* Lefebvre F, Crivelli AJ (2012) Salinity effects on anguillicolosis in Atlantic eels: a natural tool for disease control. Mar Ecol Prog Ser 471:193-202

Lefevre S (2016) Are global warming and ocean acidification conspiring against marine ectotherms? A meta-analysis of the respiratory effects of elevated temperature, high $\mathrm{CO}_{2}$ and their interaction. Conserv Physiol 4:cow009

Lefevre S, Wang $\mathrm{T}$, Jensen A, Cong NV, Huong DTT, Phuong NT, Bayley M (2014) Air-breathing fishes in aquaculture. What can we learn from physiology? J Fish Biol 84:705-731
Legendre M (1986) Seasonal changes in sexual maturity and fecundity, and HCG-induced breeding of the catfish, Heterobranchus longifilis Val. (Clariidae), reared in Ebrie Lagoon (Ivory Coast). Aquaculture 55:201-213

K Leung TLF, Bates AE (2013) More rapid and severe disease outbreaks for aquaculture at the tropics: implications for food security. J Appl Ecol 50:215-222

KLevin LA, Breitburg DL (2015) Linking coasts and seas to address ocean deoxygenation. Nat Clim Change 5: 401-403

Li S, Yang Z, Nadolnyak D, Zhang Y, Luo Y (2016) Economic impacts of climate change: profitability of freshwater aquaculture in China. Aquacult Res 47:1537-1548

Liao IC, Chao NH (2009) Aquaculture and food crisis: opportunities and constraints. Asia Pac J Clin Nutr 18:564-569

Lin M, Li Z, Liu J, Gozlan RE and others (2015) Maintaining economic value of ecosystem services whilst reducing environmental cost: a way to achieve freshwater restoration in China. PLOS ONE 10:e0120298

* Lindegren M, Checkley DM, Rouyer T, MacCall AD, Stenseth NC (2013) Climate, fishing, and fluctuations of sardine and anchovy in the California Current. Proc Natl Acad Sci USA 110:13672-13677

* Liu Y, Saitoh SI, Maekawa K, Mochizuki KI, Tian Y (2018) Impact of short-term climate effects and sea ice coverage variation on Japanese scallop aquaculture in Saroma Lake, Japan. Aquacult Res 49:1752-1767

KLõhmus M, Björklund M (2015) Climate change: What will it do to fish-parasite interactions? Biol J Linn Soc 116: 397-411

L Lorentzen T (2008) Modeling climate change and the effect on the Norwegian salmon farming industry. Nat Resour Model 21:416-435

* Lü W, Li W, Ke C, Wang H (2017) Reproductive success under the joint influences of temperature and salinity in noble scallop, Chlamys nobilis (Reeve). Aquacult Res 48: 686-696

Luening E (2013) After the hurricane. Aquaculture North America 4(2):1

*Lupatsch I, Kissil GW (2005) Feed formulations based on energy and protein demands in white grouper (Epinephelus aeneus). Aquaculture 248:83-95

MacKenzie BR, Köster FW (2004) Fish production and climate: sprat in the Baltic Sea. Ecology 85:784-794

* MacLeod CD (2017) Parasitic infection: a missing piece of the ocean acidification puzzle. ICES J Mar Sci 74: 929-933

* Magnadóttir B (2006) Innate immunity of fish (overview). Fish Shellfish Immunol 20:137-151

* Mantua NJ, Hare SR, Zhang Y, Wallace JM, Francis RC (1997) A Pacific interdecadal climate oscillation with impacts on salmon production. Bull Am Meteorol Soc 78: 1069-1079

* Marcogliese DJ (2001) Implications of climate change for parasitism of animals in the aquatic environment. Can J Zool 79:1331-1352

Marcogliese DJ (2008) The impact of climate change on the parasites and infectious diseases of aquatic animals. Rev Sci Tech 27:467-484

*Marcogliese DJ (2016) The distribution and abundance of parasites in aquatic ecosystems in a changing climate: more than just temperature. Integr Comp Biol 56: 611-619

* Marcos-López M, Gale P, Oidtmann BC, Peeler EJ (2010) Assessing the impact of climate change on disease emer- 
gence in freshwater fish in the United Kingdom. Transbound Emerg Dis 57:293-304

Martin LB, Hopkins WA, Mydlarz LD, Rohr JR (2010) The effects of anthropogenic global changes on immune functions and disease resistance. Ann N Y Acad Sci 1195: 129-148

Matozzo V, Chinellato A, Munari M, Finos L, Bressan M, Marin MG (2012) First evidence of immunomodulation in bivalves under seawater acidification and increased temperature. PLOS ONE 7:e33820

McClure CA, Hammell KL, Moore M, Dohoo IR, Burnley H (2007) Risk factors for early sexual maturation in Atlantic salmon in seawater farms in New Brunswick and Nova Scotia, Canada. Aquaculture 272:370-379

McCoy D, McManus MA, Kotubetey K, Kawelo AH and others (2017) Large-scale climatic effects on traditional Hawaiian fishpond aquaculture. PLOS ONE 12:e018 7951

Merino G, Barange M, Mullon C (2010) Climate variability and change scenarios for a marine commodity: modelling small pelagic fish, fisheries and fishmeal in a globalized market. J Mar Syst 81:196-205

Miegel RP, Pain SJ, van Wettere WHEJ, Howarth GS, Stone DAJ (2010) Effect of water temperature on gut transit time, digestive enzyme activity and nutrient digestibility in yellowtail kingfish (Seriola lalandi). Aquaculture 308: 145-151

Miles H, Widdicombe S, Spicer JI, Hall-Spencer J (2007) Effects of anthropogenic seawater acidification on acidbase balance in the sea urchin Psammechinus miliaris. Mar Pollut Bull 54:89-96

Miller AW, Reynolds AC, Sobrino C, Riedel GF (2009) Shellfish face uncertain future in high $\mathrm{CO}_{2}$ world: influence of acidification on oyster larvae calcification and growth in estuaries. PLOS ONE 4:e5661

Miller GM, Kroon FJ, Metcalfe S, Munday PL (2015) Temperature is the evil twin: effects of increased temperature and ocean acidification on reproduction in a reef fish. Ecol Appl 25:603-620

Miller SH, Breitburg DL, Burrell RB, Keppel AG (2016) Acidification increases sensitivity to hypoxia in important forage fishes. Mar Ecol Prog Ser 549:1-8

Morash AJ, Alter K (2016) Effects of environmental and farm stress on abalone physiology: perspectives for abalone aquaculture in the face of global climate change. Rev Aquacult 8:342-368

Morgan IJ, McDonald DG, Wood Chris M (2001) The cost of living for freshwater fish in a warmer, more polluted world. Glob Change Biol 7:345-355

* Mouritsen KN, Poulin R (2002) Parasitism, climate oscillations and the structure of natural communities. Oikos 97: $462-468$

Munoz NJ, Farrell AP, Heath JW, Neff BD (2015) Adaptive potential of a Pacific salmon challenged by climate change. Nat Clim Change 5:163-166

Murdiyarso D, Purbopuspito J, Kauffman JB, Warren MW and others (2015) The potential of Indonesian mangrove forests for global climate change mitigation. Nat Clim Change 5:1089-1092

* Mydlarz LD, Jones LE, Harvell CD (2006) Innate immunity, environmental drivers, and disease ecology of marine and freshwater invertebrates. Annu Rev Ecol Evol Syst 37:251-288

Ng WK, Sigholt T, Gordon Bell J (2004) The influence of environmental temperature on the apparent nutrient and fatty acid digestibility in Atlantic salmon (Salmo salar L.) fed finishing diets containing different blends of fish oil, rapeseed oil and palm oil. Aquacult Res 35:1228-1237

* Nguyen AL, Dang VH, Bosma RH, Verreth JAJ, Leemans R, De Silva SS (2014) Simulated impacts of climate change on current farming locations of striped catfish (Pangasianodon hypophthalmus; Sauvage) in the Mekong Delta, Vietnam. Ambio 43:1059-1068

Nguyen LA, Verreth JAJ, Leemans R, Bosma R, De Silva S (2016) A decision tree analysis to support potential climate change adaptations of striped catfish (Pangasianodon hypophthalmus Sauvage) farming in the Mekong Delta, Vietnam. Tropicultura 34:105-115

Nouyen LA, Pham TBV, Bosma R, Verreth J, Leemans R, De Silva S, Lansink AO (2018) Impact of climate change on the technical efficiency of striped catfish, Pangasianodon hypophthalmus, farming in the Mekong Delta, Vietnam. J World Aquacult Soc 49:570-581

Nilsson GE, Dixson DL, Domenici P, McCormick MI, Sorensen C, Watson SA, Munday PL (2012) Near-future carbon dioxide levels alter fish behaviour by interfering with neurotransmitter function. Nat Clim Change 2:201-204

NOAA (2011) Washington shellfish initiative. National Oceanic and Atmospheric Administration's National Shellfish Initiative. https://www.governor.wa.gov/sites/ default/files/documents/WSI_WhitePaper2001.pdf

NRC (2011) Dietary energy utilization and metabolic integration. Nutrient requirements of fish and shrimp. The National Academies, Washington, DC, p 34-56

${ }^{\circ}$ 'Brien PA, Morrow KM, Willis B, Bourne D (2016) Implications of ocean acidification for marine microorganisms from the free-living to the host-associated. Front Mar Sci $3: 47$

* O'Donnell MJ, George MN, Carrington E (2013) Mussel byssus attachment weakened by ocean acidification. Nat Clim Change 3:587-590

O Okamura B (2016) Hidden infections and changing environments. Integr Comp Biol 56:620-629

* Okamura B, Feist SW (2011) Emerging diseases in freshwater systems. Freshw Biol 56:627-637

Ólafsson EB, Peterson CH, Ambrose WG Jr (1994) Does recruitment limitation structure populations and communities of macroinvertebrates in marine soft sediments: the relative significance of pre-and post-settlement processes. Oceanogr Mar Biol Annu Rev 32:65-109

Olson CE, Roberts SB (2014) Genome-wide profiling of DNA methylation and gene expression in Crassostrea gigas male gametes. Front Physiol 5:224

Orchard SE, Stringer LC, Quinn CH (2015) Impacts of aquaculture on social networks in the mangrove systems of northern Vietnam. Ocean Coast Manag 114:1-10

\% Overstreet RM (2007) Effects of a hurricane on fish parasites. Parassitologia 49:161-168

Padilla DK, Savedo MM (2013) A systematic review of phenotypic plasticity in marine invertebrate and plant systems. Adv Mar Biol 65:67-94

*Padilla-Gamiño JL, Kelly MW, Evans TG, Hofmann GE (2013) Temperature and $\mathrm{CO}_{2}$ additively regulate physiology, morphology and genomic responses of larval sea urchins, Strongylocentrotus purpuratus. Proc R Soc B 280:20130155

Page F, Losier RJ, McCurdy P, Greenberg DA, Chaffey J, Change B (2005) Dissolved oxygen and salmon cage culture. In: Hargrave B (ed) Environmental effects of marine finfish aquaculture. Springer, New York, NY, p 1-28 
Pankhurst NW, Munday PL (2011) Effects of climate change on fish reproduction and early life history stages. Mar Freshw Res 62:1015-1026

*Pankhurst NW, King HR, Anderson K, Elizur A, Pankhurst PM, Ruff N (2011) Thermal impairment of reproduction is differentially expressed in maiden and repeat spawning Atlantic salmon. Aquaculture 316:77-87

Parisi MG, Mauro M, Sara G, Cammarata M (2017) Temperature increases, hypoxia, and changes in food availability affect immunological biomarkers in the marine mussel Mytilus galloprovincialis. J Comp Physiol B Biochem Syst Environ Physiol 187:1117-1126

Parker LM, Ross PM, O'Connor WA (2009) The effect of ocean acidification and temperature on the fertilization and embryonic development of the Sydney rock oyster Saccostrea glomerata (Gould 1850). Glob Change Biol 15:2123-2136

Parker LM, Ross PM, O'Connor WA (2010) Comparing the effect of elevated $\mathrm{pCO}_{2}$ on the fertilization and early development of two species of oysters. Mar Biol 157: 2435-2452

* Parker LM, Ross PM, O'Connor WA (2011) Populations of the Sydney rock oyster, Saccostrea glomerata, vary in response to ocean acidification. Mar Biol 158:689-697

* Parker LM, Ross PM, O'Connor WA, Borysko L, Raftos DA, Pörtner HO (2012) Adult exposure influences offspring response to ocean acidification in oysters. Glob Change Biol 18:82-92

'Parker LM, Ross PM, O'Connor WA, Pörtner HO, Scanes E, Wright JM (2013) Predicting the response of molluscs to the impact of ocean acidification. Biology (Basel) 2: 651-692

Parker LM, O'Connor WA, Byrne M, Coleman RA and others (2017) Adult exposure to ocean acidification is maladaptive for larvae of the Sydney rock oyster Saccostrea glomerata in the presence of multiple stressors. Biol Lett 13:20160798

Pauly D, Zeller D (2016) Catch reconstructions reveal that global marine fisheries catches are higher than reported and declining. Nat Commun 7:10244

* Pedersen MW, Kokkalis A, Bardarson H, Bonanomi S and others (2016) Trends in marine climate change research in the Nordic region since the first IPCC report. Clim Change 134:147-161

Pérez-Casanova JC, Rise ML, Dixon B, Afonso LOB, Hall JR, Johnson SC, Gamperl AK (2008) The immune and stress responses of Atlantic cod to long-term increases in water temperature. Fish Shellfish Immunol 24:600-609

Piao S, Ciais P, Huang Y, Shen Z and others (2010) The impacts of climate change on water resources and agriculture in China. Nature 467:43-51

Pickering TD, Ponia B, Hair CA, Southgate P and others (2011) Vulnerability of aquaculture in the tropical Pacific to climate change. In: Bell JD, Johnson JE, Hobday AJ (eds) Vulnerability of tropical Pacific fisheries and aquaculture to climate change. Secretariat of the Pacific Community, Noumea, p 647-731

Pimentel MS, Faleiro F, Marques T, Bispo R and others (2016) Foraging behaviour, swimming performance and malformations of early stages of commercially important fishes under ocean acidification and warming. Clim Change 137:495-509

Pinsky ML, Worm B, Fogarty MJ, Sarmiento JL, Levin SA (2013) Marine taxa track local climate velocities. Science 341:1239-1242
Pittman K, Yúfera M, Pavlidis M, Geffen AJ and others (2013) Fantastically plastic: fish larvae equipped for a new world. Rev Aquacult 5:S224-S267

Poloczanska ES, Brown CJ, Sydeman WJ, Kiessling W and others (2013) Global imprint of climate change on marine life. Nat Clim Change 3:919-925

*Pörtner HO, Farrell AP (2008) Physiology and climate change. Science 322:690-692

* Prechtel AR, Coulter AA, Etchison L, Jackson PR, Goforth RR (2018) Range estimates and habitat use of invasive silver carp (Hypophthalmichthys molitrix): evidence of sedentary and mobile individuals. Hydrobiologia 805: 203-218

Prein AF, Rasmussen RM, Ikeda K, Liu C, Clark MP, Holland GJ (2017) The future intensification of hourly precipitation extremes. Nat Clim Change 7:48-52

* Quinn NL, McGowan CR, Cooper GA, Koop BF, Davidson WS (2011) Identification of genes associated with heat tolerance in Arctic charr exposed to acute thermal stress. Physiol Genomics 43:685-696

Rahman MM, Hossain MS (2012) Mangrove forests and aquaculture farmers: aspects of climate change adaptation on the central coast of Bangladesh. Aquacult Mag 43:12-17

Kahmani V, Hutchinson SL, Harrington JA, Hutchinson JMS (2016) Analysis of frequency and magnitude of extreme rainfall events with potential impacts on flooding: a case study from the central United States. Int J Climatol 36: 3578-3587

* Range P, Chicharo MA, Ben-Hamadou R, Piló D and others (2011) Calcification, growth and mortality of juvenile clams Ruditapes decussatus under increased $\mathrm{pCO}_{2}$ and reduced $\mathrm{pH}$ : variable responses to ocean acidification at local scales? J Exp Mar Biol Ecol 396: $177-184$

Reid GK, Jackson T (2014) Climate change sessions increasingly prominent at aquaculture meetings. Aquacult Mag 45:9-10

Reid GK, Filgueira R, Garber A (2015) Revisiting temperature effects on aquaculture in light of pending climate change. In: Wade J, Jackson T, Brewer-Dalton K (eds) Aquaculture Canada 2014. Aquaculture Association of Canada, St. Andrews, p 85-91

* Remen M, Oppedal F, Imsland AK, Olsen RE, Torgersen T (2013) Hypoxia tolerance thresholds for post-smolt Atlantic salmon: dependency of temperature and hypoxia acclimation. Aquaculture 416-417:41-47

* Remen M, Sievers M, Torgersen T, Oppedal F (2016) The oxygen threshold for maximal feed intake of Atlantic salmon post-smolts is highly temperature-dependent. Aquaculture 464:582-592

Renault T (2009) Trends and perspectives in preventing and controlling infectious diseases in molluscs. In: Nakamura TK (ed) Aquaculture research progress. Nova Science Publishers, Lancaster, p 99-126

Rhein M, Rintoul SR, Aoki S, Campos E and others (2013) Observations: ocean. In: Stocker TF, Qin D, Plattner GK, Tignor $M$ and others (eds) Climate change 2013: the physical science basis. Contribution of Working Group I to the Fifth Assessment Report of the Intergovernmental Panel on Climate Change. Cambridge University Press, Cambridge, p 255-316

Kichardson AJ, Schoeman DS (2004) Climate impact on plankton ecosystems in the Northeast Atlantic. Science 305:1609-1612 
Roberts SB, Gavery MR (2012) Is there a relationship between DNA methylation and phenotypic plasticity in invertebrates? Front Physiol 2:116

Roegner C, Andre C, Lindegarth M, Eckman JE, Grant J (1995) Transport of recently settled soft-shell clams ( $M$. arenaria L.) in laboratory flume flow. J Exp Mar Biol Ecol $187: 13-26$

Rohr JR, Dobson AP, Johnson PTJ, Kilpatrick AM and others (2011) Frontiers in climate change-disease research. Trends Ecol Evol 26:270-277

Rosa R, Marques A, Nunes ML (2012) Impact of climate change in Mediterranean aquaculture. Rev Aquacult 4: 163-177

Rowley AF, Cross ME, Culloty SC, Lynch SA and others (2014) The potential impact of climate change on the infectious diseases of commercially important shellfish populations in the Irish Sea-a review. ICES J Mar Sci 71:741-759

Russell BD, Connell SD, Mellin C, Brook BW, Burnell OW, Fordham DA (2012) Predicting the distribution of commercially important invertebrate stocks under future climate. PLOS ONE 7:e46554

Sae-Lim P, Kause A, Mulder HA, Olesen I (2017) Breeding and genetics symposium: climate change and selective breeding in aquaculture. J Anim Sci 95:1801-1812

Sallenger AH, Doran KS, Howd PA (2012) Hotspot of accelerated sea-level rise on the Atlantic coast of North America. Nat Clim Change 2:884-888

Scheibling RE, Lauzon-Guay JS (2010) Killer storms: North Atlantic hurricanes and disease outbreaks in sea urchins. Limnol Oceanogr 55:2331-2338

Schmidt D, Boyd PW (2016) Forecast ocean variability. Nature 539:162-163

Schmidtko S, Stramma L, Visbeck M (2017) Decline in global oceanic oxygen content during the past five decades. Nature 542:335

Selvam DG, Mujeeb Rahiman KM, Mohamed Hatha AA (2012) An Investigation into occasional white spot syndrome virus outbreak in traditional paddy cum prawn fields in India. Sci World J 2012:340830

Sfakianakis DG, Papadakis IE, Papadaki M, Sigelaki I, Mylonas CC (2013) Influence of rearing temperature during early life on sex differentiation, haemal lordosis and subsequent growth during the whole production cycle in European sea bass Dicentrarchus labrax. Aquaculture 412-413:179-185

Shao YT, Chang FY, Fu WC, Yan HY (2016) Acidified seawater suppresses insulin-like growth factor I mRNA expression and reduces growth rate of juvenile orangespotted groupers, Epinephelus coioides (Hamilton, 1822). Aquacult Res 47:721-731

Shelton C (2014) Climate change adaptation in fisheries and aquaculture - compilation of initial examples. FAO Fisheries and Aquaculture Circular No. 1088. FAO, Rome

* Siikavuopio SI, James P, Lysne H, Sæther BS, Samuelsen TA, Mortensen A (2012) Effects of size and temperature on growth and feed conversion of juvenile green sea urchin (Strongylocentrotus droebachiensis). Aquaculture 354-355:27-30

* Sinha E, Michalak AM, Balaji V (2017) Eutrophication will increase during the 21 st century as a result of precipitation changes. Science 357:405-408

Smajgl A, Toan TQ, Nhan DK, Ward J and others (2015) Responding to rising sea levels in the Mekong Delta. Nat Clim Change 5:167-174
Small DP, Calosi P, Boothroyd D, Widdicombe S, Spicer JI (2016) The sensitivity of the early benthic juvenile stage of the European lobster Homarus gammarus (L.) to elevated $\mathrm{pCO}_{2}$ and temperature. Mar Biol 163:1-12

Smith MD, Roheim CA, Crowder LB, Halpern BS and others (2010) Sustainability and global seafood. Science 327: 784-786

Soto D, Ross LG, Handisyde N, Bueno PB and others (2018) Climate change and aquaculture: vulnerability and adaptation options. In: Barange $M$, Bahri $T$, Beveridge MCM, Cochrane KL, Funge-Smith S, Poulain F (eds) Impacts of climate change on fisheries and aquaculture: synthesis of current knowledge, adaptation and mitigation options. Fish Aquacult Tech Pap 627. FAO, Rome, p 465-490

Sproul TW, Montanio K, Frank M (2013) The economics of climate change risk to RI oyster aquaculture. Narragansett Bay J 1:1-3

Steckbauer A, Ramajo L, Hendriks IE, Fernandez M, Lagos N, Prado L, Duarte CM (2015) Synergistic effects of hypoxia and increasing $\mathrm{CO}_{2}$ on benthic invertebrates of the central Chilean coast. Front Mar Sci 2:49

Stevenson NJ, Lewis RR, Burbridge PR (1999) Disused shrimp ponds and mangrove rehabilitation. In: Streever W (ed) An international perspective on wetland rehabilitation. Springer, Dordrecht, p 277-297

* Stock CA, Alexander MA, Bond NA, Brander KM and others (2011) On the use of IPCC-class models to assess the impact of climate on living marine resources. Prog Oceanogr 88:1-27

Stocker TF, Qin D, Plattner GK, Alexander LV and others (2013) Technical summary. In: Stocker TF, Qin D, Plattner GK, Tignor M and others (eds) Climate change 2013: the physical science basis. Contribution of Working Group I to the Fifth Assessment Report of the Intergovernmental Panel on Climate Change. Cambridge University Press, Cambridge, p 33-131

* Stramma L, Oschlies A, Schmidtko S (2012) Mismatch between observed and modeled trends in dissolved upperocean oxygen over the last 50 yr. Biogeosciences 9: 4045-4057

Stumpp M, Wren J, Melzner F, Thorndyke M, Dupont S (2011) $\mathrm{CO}_{2}$ induced seawater acidification impacts sea urchin larval development. I. Elevated metabolic rates decrease scope for growth and induce developmental delay. Comp Biochem Physiol A Mol Integr Physiol 160: 331-340

Stumpp M, Hu M, Casties I, Saborowski R, Bleich M, Melzner F, Dupont S (2013) Digestion in sea urchin larvae impaired under ocean acidification. Nat Clim Change 3: 1044-1049

Suckling CC, Clark MS, Beveridge C, Brunner L and others (2014) Experimental influence of $\mathrm{pH}$ on the early lifestages of sea urchins. II. Increasing parental exposure times gives rise to different responses. Invertebr Reprod Dev 58:161-175

* Suckling CC, Clark MS, Richard J, Morley SA, Thorne MAS, Harper EM, Peck LS (2015) Adult acclimation to combined temperature and $\mathrm{pH}$ stressors significantly enhances reproductive outcomes compared to short-term exposures. J Anim Ecol 84:773-784

Sui Y, Kong H, Shang Y, Huang X and others (2016) Effects of short-term hypoxia and seawater acidification on hemocyte responses of the mussel Mytilus coruscus. Mar Pollut Bull 108:46-52 
Sunday JM, Calosi P, Dupont S, Munday PL, Stillman JH, Reusch TBH (2014) Evolution in an acidifying ocean. Trends Ecol Evol 29:117-125

* Sung YY, MacRae TH, Sorgeloos P, Bossier P (2011) Stress response for disease control in aquaculture. Rev Aquacult 3:120-137

Swanson AK, Fox CH (2007) Altered kelp (Laminariales) phlorotannins and growth under elevated carbon dioxide and ultraviolet-B treatments can influence associated intertidal food webs. Glob Change Biol 13:1696-1709

Sydeman WJ, García-Reyes M, Schoeman DS, Rykaczewski RR, Thompson SA, Black BA, Bograd SJ (2014) Climate change and wind intensification in coastal upwelling ecosystems. Science 345:77-80

Tacon AGJ, Metian M (2015) Feed matters: satisfying the feed demand of aquaculture. Rev Fish Sci Aquacult 23: $1-10$

Tacon AGJ, Metian M, Turchini GM, De Silva SS (2009) Responsible aquaculture and trophic level implications to global fish supply. Rev Fish Sci 18:94-105

Tahil AS, Dy DT (2016) Effects of reduced pH on the early larval development of hatchery-reared donkey's ear abalone, Haliotis asinina (Linnaeus 1758). Aquaculture 459:137-142

Takarina ND, Wardhana W, Soedjiarti T (2017) Impact of oxygen depletion on planktonic community with emphasis temperature dynamics at aquaculture scale in Blanakan, West Java. AIP Conf Proc 1848:1-6

Talmage SC, Gobler CJ (2009) The effects of elevated carbon dioxide concentrations on the metamorphosis, size, and survival of larval hard clams (Mercenaria mercenaria), bay scallops (Argopecten irradians), and eastern oysters (Crassostrea virginica). Limnol Oceanogr 54: 2072-2080

* Talmage SC, Gobler CJ (2011) Effects of elevated temperature and carbon dioxide on the growth and survival of larvae and juveniles of three species of Northwest Atlantic bivalves. PLOS ONE 6:e26941

Taris N, Ernande B, McCombie H, Boudry P (2006) Phenotypic and genetic consequences of size selection at the larval stage in the Pacific oyster (Crassostrea gigas). J Exp Mar Biol Ecol 333:147-158

Taris N, Batista FM, Boudry P (2007) Evidence of response to unintentional selection for faster development and inbreeding depression in Crassostrea gigas larvae. Aquaculture 272:S69-S79

Thiyagarajan V, Ko GWK (2012) Larval growth response of the Portuguese oyster (Crassostrea angulata) to multiple climate change stressors. Aquaculture 370-371: 90-95

* Thomsen J, Gutowska MA, Saphörster J, Heinemann A and others (2010) Calcifying invertebrates succeed in a naturally $\mathrm{CO}_{2}$-rich coastal habitat but are threatened by high levels of future acidification. Biogeosciences 7:3879-3891

* Thomsen J, Casties I, Pansch C, Körtzinger A, Melzner F (2013) Food availability outweighs ocean acidification effects in juvenile Mytilus edulis: laboratory and field experiments. Glob Change Biol 19:1017-1027

Thomsen J, Stapp LS, Haynert K, Schade H and others (2017) Naturally acidified habitat selects for ocean acidificationtolerant mussels. Sci Adv 3:e1602411

* Timmins-Schiffman E, O'Donnell M, Friedman C, Roberts S (2013) Elevated $\mathrm{pCO}_{2}$ causes developmental delay in early larval Pacific oysters, Crassostrea gigas. Mar Biol 160:1973-1982
Tully K, Gedan K, Epanchin-Niell R, Strong A and others (2019) The invisible flood: the chemistry, ecology, and social implications of coastal saltwater intrusion. Bioscience 69:368-378

UNEP-WCMC (United Nations Environment ProgrammeWorld Conservation Monitoring Centre) (2006) In the front line: shoreline protection and other ecosystem services from mangroves and coral reefs. UNEP-WCMC, Cambridge

*Utoh T, Horie N, Okamura A, Mikawa N and others (2013) Water temperature manipulation can induce oocyte maturation and ovulation in the common Japanese conger, Conger myriaster. Aquaculture 392-395:120-127

* van Vliet MTH, Franssen WHP, Yearsley JR, Ludwig F, Haddeland I, Lettenmaier DP, Kabat P (2013) Global river discharge and water temperature under climate change. Glob Environ Change 23:450-464

*Vivekanandan E, Hermes R, O'Brien C (2016) Climate change effects in the Bay of Bengal large marine ecosystem. Environ Dev 17(Suppl 1):46-56

*Waldbusser GG, Bergschneider H, Green MA (2010) Sizedependent $\mathrm{pH}$ effect on calcification in post-larval hard clam Mercenaria spp. Mar Ecol Prog Ser 417:171-182

*Waldbusser GG, Voigt EP, Bergschneider H, Green MA, Newell RIE (2011) Biocalcification in the eastern oyster (Crassostrea virginica) in relation to long-term trends in Chesapeake Bay pH. Estuaries Coasts 34:221-231

WWaldbusser GG, Hales B, Langdon CJ, Haley BA and others (2015) Saturation-state sensitivity of marine bivalve larvae to ocean acidification. Nat Clim Change 5:273-280

*Wang Q, Cheng L, Liu J, Li Z, Xie S, De Silva SS (2015) Freshwater aquaculture in PR China: trends and prospects. Rev Aquacult 7:283-302

*Wang Y, Hu M, Wong WH, Shin PK, Cheung SG (2011) The combined effects of oxygen availability and salinity on physiological responses and scope for growth in the green-lipped mussel Perna viridis. Mar Pollut Bull 63: 255-261

*Wang Y, Hu M, Cheung SG, Shin PKS, Lu W, Li J (2012) Immune parameter changes of hemocytes in greenlipped mussel Perna viridis exposure to hypoxia and hyposalinity. Aquaculture 356-357:22-29

*Wassmann R, Hien NX, Hoanh CT, Tuong TP (2004) Sea level rise affecting the Vietnamese Mekong Delta: water elevation in the flood season and implications for rice production. Clim Change 66:89-107

Watson SA, Southgate PC, Tyler PA, Peck LS (2009) Early larval development of the Sydney rock oyster Saccostrea glomerata under near-future predictions of $\mathrm{CO}_{2}$-driven ocean acidification. J Shellfish Res 28:431-437

Watson SA, Southgate PC, Miller GM, Moorhead JA, Knauer J (2012) Ocean acidification and warming reduce juvenile survival of the fluted giant clam, Tridacna squamosa. Molluscan Res 32:177-180

* Weber MJ, Hennen MJ, Brown ML, Lucchesi DO, St. Sauver TR (2016) Compensatory response of invasive common carp Cyprinus carpio to harvest. Fish Res 179:168-178

* Welch MJ, Watson SA, Welsh JQ, McCormick MI, Munday PL (2014) Effects of elevated $\mathrm{CO}_{2}$ on fish behaviour undiminished by transgenerational acclimation. Nat Clim Change 4:1086-1089

Wells ML, Trainer VL (2016) International Scientific Symposium on 'Harmful algal blooms and climate change'. PICES Press 24:16-17

Widdicombe S, Spicer JI (2008) Predicting the impact of 
ocean acidification on benthic biodiversity: What can animal physiology tell us? J Exp Mar Biol Ecol 366:187-197

Wikfors GH, Ohno M (2001) Impact of algal research in aquaculture. J Phycol 37:968-974

Wilkinson RJ, Longland R, Woolcott H, Porter MJR (2010) Effect of elevated winter-spring water temperature on sexual maturation in photoperiod manipulated stocks of rainbow trout (Oncorhynchus mykiss). Aquaculture 309: 236-244

Windell JT, Foltz JW, Sarokon JA (1978) Effect of fish size, temperature, and amount fed on nutrient digestibility of a pelleted diet by rainbow trout, Salmo gairdneri. Trans Am Fish Soc 107:613-616

Winsemius HC, Aerts JCJH, van Beek LPH, Bierkens MFP and others (2016) Global drivers of future river flood risk. Nat Clim Change 6:381-385

Wood HL, Spicer JI, Widdicombe S (2008) Ocean acidification may increase calcification rates, but at a cost. Proc $\mathrm{R}$ Soc B 275:1767-1773

World Bank (2013) Fish to 2030: prospects for fisheries and aquaculture. Rep 83177-GLB. World Bank, Washington, DC

World Bank (2015) The sunken billions revisited: progress and challenges in global marine fisheries. www.worldbank.org/en/topic/environment/brief/the-sunken-billionsrevisited-progress-and-challenges-in-global-marinefisheries (accessed 30 March 2017)

WSBR Panel (Washington Shellfish Initiative Blue Ribbon Panel on Ocean Acidification) (2012) Scientific summary of ocean acidification in Washington State marine waters. NOAA OAR Spec Rep. https://fortress.wa.gov/ ecy/publications/documents/1201016.pdf

Xu X, Goswami S, Gulledge J, Wullschleger SD, Thornton PE

Editorial responsibility: Symon Dworjanyn,

Coffs Harbour, New South Wales, Australia
(2016) Interdisciplinary research in climate and energy sciences. Wiley Interdiscip Rev Energy Environ 5:49-56

* Zambonino-Infante JL, Claireaux G, Ernande B, Jolivet A, and others (2013) Hypoxia tolerance of common sole juveniles depends on dietary regime and temperature at the larval stage: evidence for environmental conditioning. Proc R Soc B 280:20123022

Zamora LN, Jeffs AG (2012) Feeding, metabolism and growth in response to temperature in juveniles of the Australasian sea cucumber, Australostichopus mollis. Aquaculture 358-359:92-97

Kell R, Krumbholz A, Wutzler P (2008) Impact of global warming on viral diseases: What is the evidence? Curr Opin Biotechnol 19:652-660

Zha S, Liu S, Su W, Shi W, Xiao G, Yan M, Liu G (2017) Laboratory simulation reveals significant impacts of ocean acidification on microbial community composition and host-pathogen interactions between the blood clam and Vibrio harveyi. Fish Shellfish Immunol 71:393-398

Zhai L, Greenan B, Hunter J, James T, Han G, Thomson R, MacAulay P (2014) Estimating sea-level allowances for the coasts of Canada and the adjacent United States using the Fifth Assessment Report of the IPCC. Can Tech Rep Hydrogr Ocean Sci. Fisheries and Oceans Canada

* Zhang Y, Xu Y, Dong W, Cao L, Sparrow M (2006) A future climate scenario of regional changes in extreme climate events over China using the PRECIS climate model. Geophys Res Lett 33:L24702

K Zhao L, Yang F, Milano S, Han T, Walliser EO, Schöne BR (2018) Transgenerational acclimation to seawater acidification in the Manila clam Ruditapes philippinarum: preferential uptake of metabolic carbon. Sci Total Environ 627:95-103

Submitted: December 6, 2017; Accepted: August 1, 2019

Proofs received from author(s): November 8, 2019 